\title{
Two-season agriculture and irrigated rice during the Dian: radiocarbon dates and archaeobotanical remains from Dayingzhuang, Yunnan, Southwest China
}

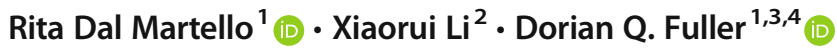 \\ Received: 3 October 2020 / Accepted: 17 December 2020 / Published online: 13 March 2021 \\ (C) The Author(s) 2021, corrected publication 2021
}

\begin{abstract}
Historical sources describe irrigation and intensive agriculture being practiced in lowland Yunnan from at least the first century $\mathrm{AD}$, but so far archaeobotanical remains allowing investigation of this issue have been scarce. Here, we present new archaeobotanical evidence, including macro-botanical and phytoliths results, from the Dian settlement site of Dayingzhuang, with direct AMS radiocarbon dates on two wheat grains falling between 750 and 390 BC. We compare these results with contemporary Dian sites and analyse the agricultural systems in Central Yunnan between the eight and fourth centuries BC. We propose that agriculture was intensified toward the end of the Dian through both multiple cropping seasons and increased evidence for irrigated rice fields.
\end{abstract}

Keywords Bronze Age $\cdot$ Archaeobotany $\cdot$ Oryza $\cdot$ Millet $\cdot$ Wheat $\cdot$ Southwestern barbarians

\section{Introduction}

The subsistence of people living in Yunnan prior and during the Dian Culture has been a topic of recent interest (i.e. Dal Martello 2020; Wu et al. 2019; Yao 2016; YPICRA et al. 2015; Yao and Jiang 2012). Formerly known as "Shizhaishan Culture", archaeological evidence now associated with the Dian was first discovered in 1955 during the excavation of the burial site of the same name. Shizhaishan cemetery is located on the Southwestern bank of the Lake Dian; sophisticated bronze objects were found in the graves, including weapons, drum-shaped cowrie shell containers, and most notably a gold seal bearing the inscription: "The Seal of the King of Dian" (see Yao 2017; Yao and Jiang 2012;

Dorian Q. Fuller

d.fuller@ucl.ac.uk

1 Department of Archaeology, Max Planck Institute for the Science of Human History, Kahlaische Strasse 10, 07745 Jena, Germany

2 Yunnan Province Institute of Cultural Relics and Archaeology, Kunming 650118, China

3 Institute of Archaeology, University College London, 31-34 Gordon Square, London WC1H OPY, UK

4 School of Cultural Heritage, Northwest University, Xi'an 710069 , China
Yunnan 1963). This led to the hypothesis that the Dian Culture was part of the "Southwestern Barbarians" as referred to in early Chinese historical texts (see for example the Shiji, 史记 Records of a Grand Historian; Shiji 116; Qian 1993; Yunnan 1963). According to current archaeological evidence, the Dian were present in Yunnan from at least the eighth century $\mathrm{BC}$, until they were conquered by the Han Dynasty in 109 BC (Zhang 1997; Allard 1999).

Direct archaeobotanical evidence from Dian sites has only recently began to become available, and most previous theories on Dian subsistence practices drew from historical records, written by Han historians following 109 BC. These describe the presence of irrigated rice fields in Yunnan's lowlands from at least 16 AD (Yao et al. 2015). Funerary clay figurines of rice paddy fields have been recovered from first century AD Han-style graves in Dali, Dian and Gejiu (Yao 2016). These are usually interpreted as a reflection of the deceased possessions and lifestyle before death, and would, therefore, further attest to the presence of irrigated rice cultivation in Yunnan from at least the first century AD. Paleo-environmental studies on Lake Dian sediments indicate abrupt changes in the palynological records from the fifth century BC; this has been interpreted as a possible indication of the beginning of irrigation and terracing activities (Sun et al. 1986; Xiao et al. 2020). However, others have instead argued against such an early date for irrigation 
in Central Yunnan, with lake sediments from the nearby Lake Xingyun, located about $70 \mathrm{~km}$ southeast from the Lake Dian, showing minimal impact on lake water management before 500 AD (Hillman et al. 2014). The Lake Dian is surrounded by alluvial plains which would have provided suitable soil for intensive agricultural production through irrigation; however, conclusive evidence for when exactly irrigation practices and intensification of agriculture started in Yunnan is still lacking.

In this paper, we present archaeobotanical evidence and direct radiocarbon dates from the recently excavated site of Dayingzhuang, a Dian settlement site situated less than $40 \mathrm{~km}$ away from the modern capital city of Kunming (Fig. 1). The site sits at the mouth of the Tanglang River, which flows into the Lake Dian and connects its western bank to the Anning area, a centre for the production of copper during the Dian (YPICRA et al. 2015). There is an excavated cemetery in this area (YPAT 1965) and additional contemporary settlement sites along the upper and lower Tanglang Basin that attest to contacts between the broader Dian Basin with the Jinsha Basin, in the northwest of the province (YPICRA et al. 2015). Foxtail millet (Setaria italica) was reported from flotation samples collected from an exposed pit profile at Dayingzhuang during a survey in 2010 (YPICRA et al. 2015: 158); however, no formal archaeobotanical report was published. Here, we present for the first time archaeobotanical results from 30 flotation and 11 phytolith samples systematically collected during the 2017 excavation and discuss Dian subsistence in light of the recently accumulated archaeobotanical record.

\section{The site of Dayingzhuang}

\section{Environment and excavation}

The Dian Basin takes its name from the Lake Dian, the largest water reservoir in Yunnan province, and the sixth largest of the whole country, with a total area of $298 \mathrm{~km}^{2}$. The Dian Basin sits in the middle of the Yungui Plateau, which presents an average altitude of $1886 \mathrm{~m}$ asl. Modern climate conditions are very mild, and Kunming is known as the "city of the eternal spring" due to its year-round spring-like conditions. Here, annual average temperature is $15.7^{\circ} \mathrm{C}$, temperature differences between seasons is small; there are at least 240 frost-free days, about $2200 \mathrm{~h}$ of sun per year, and an annual average precipitation of $960 \mathrm{~mm}$ occurring mostly between the months of May and August, with a recorded average precipitation of $203.1 \mathrm{~mm}$ in July only in the last 30 years (Xiao et al. 2020; Zhao 1986). Dayingzhuang is located c. $37 \mathrm{~km}$ southwest from Kunming, and only $13 \mathrm{~km}$ from the north-western bank of the Lake Dian,

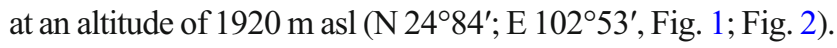
This creates modern weather conditions slightly colder than at Kunming, with an annual average temperature of $13.2^{\circ} \mathrm{C}$ (coldest attested temperatures are around $-8{ }^{\circ} \mathrm{C}$ in January and hottest attested temperatures around $28^{\circ} \mathrm{C}$ in July). A rather high average daily thermal excursion of around $9.4^{\circ} \mathrm{C}$ is reported; frost-free days varies between 180 and 220 per year (Zhao 1986). Modern agricultural production in the Yungui plateau is rich, with double cropping of rice and winter wheat (Zhao 1994; Bray 1984; NBS 2019).

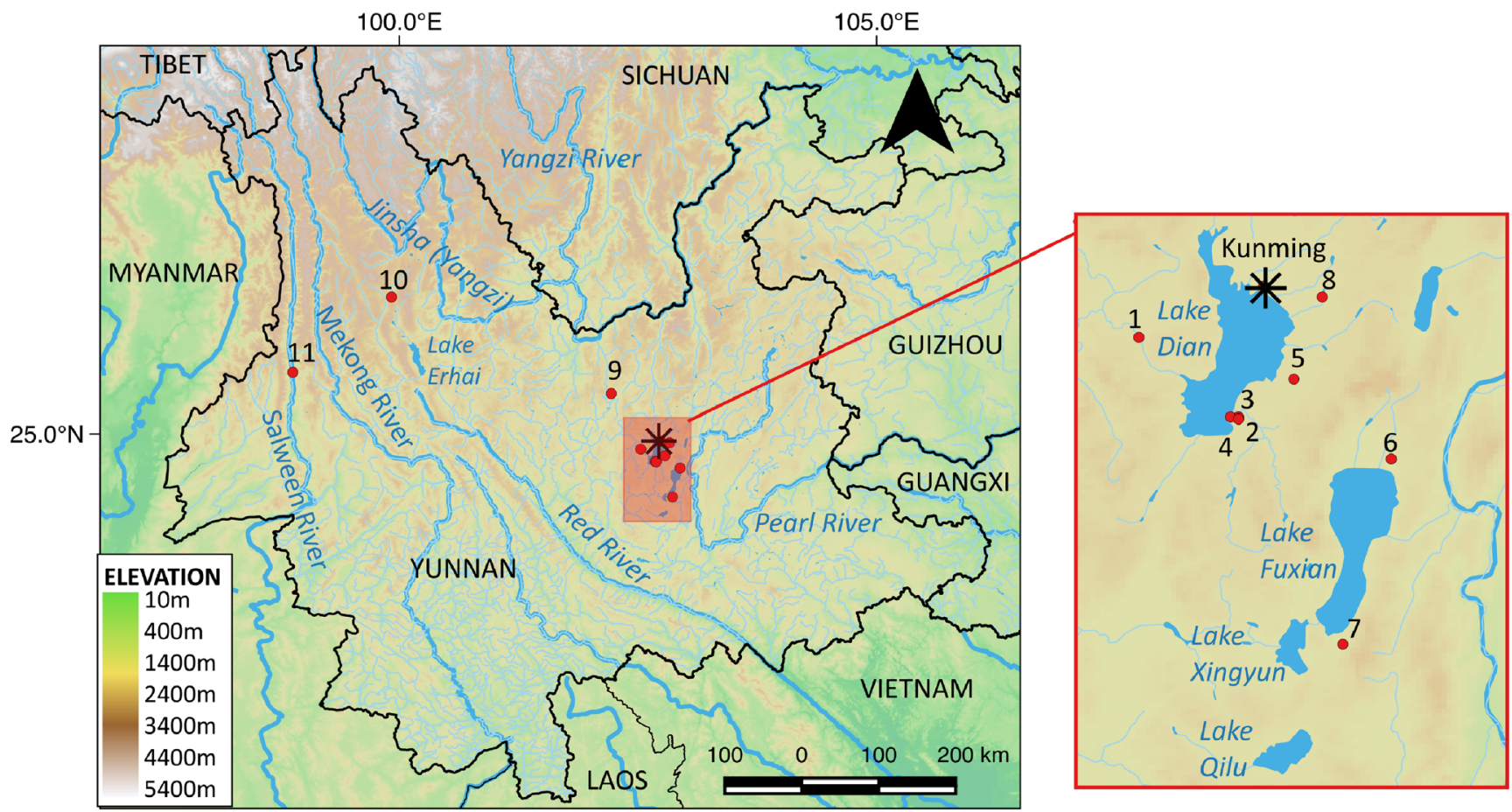

Fig. 1 Map showing location of Bronze Age sites in Yunnan mentioned in text: 1. Dayingzhuang; 2. Shizhaishan; 3. Hebosuo; 4. Shangxihe; 5. Anjiang; 6. Xueshan; 7. Guangfentou; 8. Xiaogucheng; 9. Yubeidi; 10. Haimenkou; 11. Shilinggang. Made with QGIS 3.10 .10 


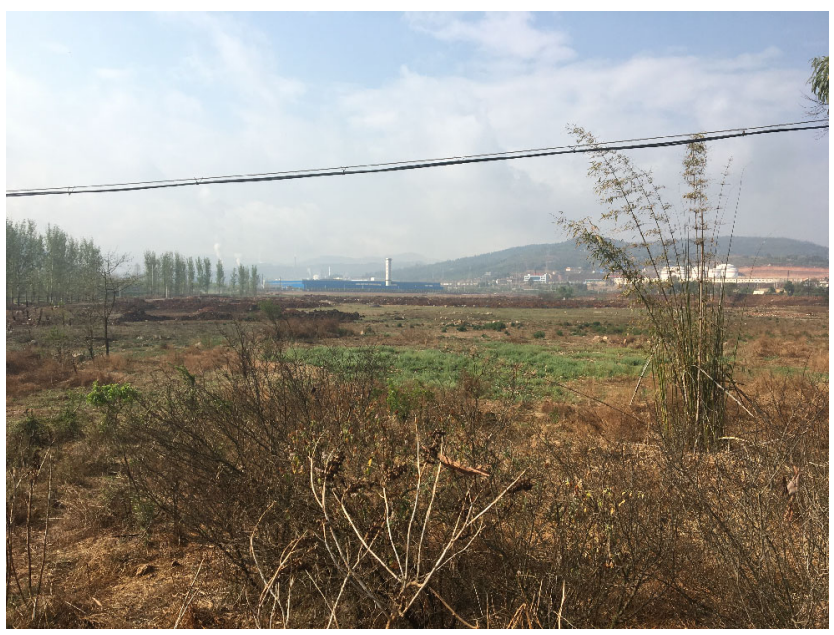

Fig. 2 Modern day surroundings at the site of Dayingzhuang, facing North. Photo by Rita Dal Martello

Paleo-environmental studies from lake sediments and pollen remains in Yunnan indicate that during the mid-2nd millennium $\mathrm{BC}$ the summer monsoon intensity decreased, temperatures cooled, and the broad-leaved forest declined. Lake sediments from the province show an increased presence of disturbance taxa, possible indication of greater human activity and modification of the natural landscape (i.e. Xiao et al. 2020; Dearing et al. 2008; Shen et al. 2005). A sharp drop event in the monsoon intensity took place at around 1500 BC (Dykoski et al. 2005; Hillman et al. 2017); this brought the environmental conditions of the province close to those of the present day, as described above. Recent pollen analysis from Lake Dian sediments has shown an increased fire activity as well as an increased presence of Poaceae remains over the 1st millennium BC (Xiao et al. 2020).

Dayingzhuang is a shell-midden site first discovered in 2010 during a 3-year archaeological survey led by the Yunnan Province Institute of Archaeology, Michigan University, and the Anthropology Museum in Toronto (YPICRA et al. 2015; Yao and Jiang 2012). The imminent construction of a tobacco factory at Dayingzhuang led to a rescue campaign being carried out between March and May 2017. A total area of $500 \mathrm{~m}^{2}$ was excavated divided in 4 square trenches of $10 \times 10 \mathrm{~m}^{2}$ each, and five additional trenches measuring respectively one $2 \times 30 \mathrm{~m}^{2}$, one $2 \times 14 \mathrm{~m}^{2}$, and three $2 \times 2 \mathrm{~m}^{2}$ (Fig. 3). Five total stratigraphic layers including two modern layers were individuated and reached a total depth of c. $2.8 \mathrm{~m}$ (Fig. 4). The total estimated size of the site is between 40,000 and $100,000 \mathrm{~m}^{2}$ (YPICRA et al. 2015).

\section{Chronometric results: dates and sequences}

During the 2010 Dian Basin survey, one radiocarbon date for the site of Dayingzhuang was published in YPICRA et al. (2015), furnishing a date of 780-550 BC (YPICRA et al.

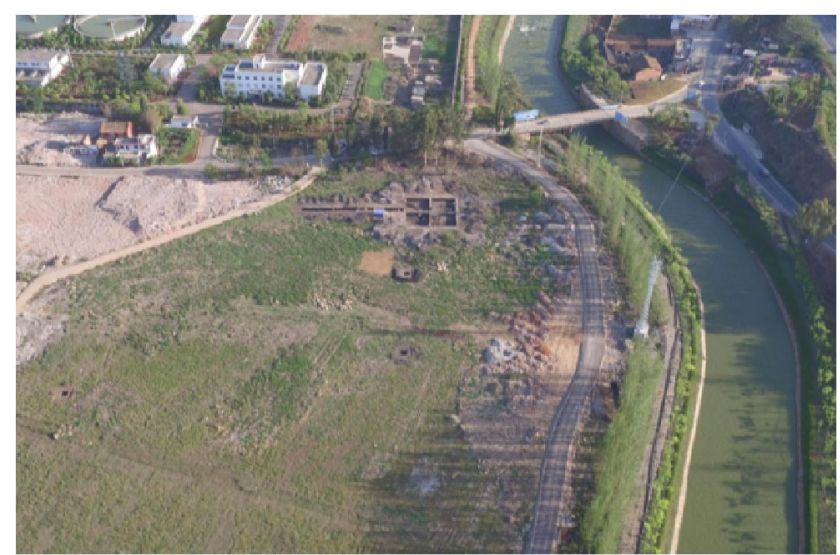

Fig. 3 Arieal view of the excavation at Dayingzhuang. Photo by $\mathrm{Li}$ Xiaorui

2015: 158; see Table 1). However, the dating material used for this date is unknown, presumably bulk charcoal. Following the 2017 excavation and the collection of archaeobotanical samples, further material was available for dating, and in summer 2018 wheat grains from contexts 2017YHD(2)S4; 2017YHD(4)S4; 2017YHD(5)S1, corresponding to layer 2, 4 and 5, were submitted to the Beta Analytic Ltd. London BioScience Innovation Centre for AMS radiocarbon dating. While a wheat grain from Layer 2 appeared intrusive (ca. $100 \mathrm{BP}$ ), the other two dates fell in the calibration plateau, between ca. $750 \mathrm{BC}$ and $390 \mathrm{BC}$, like the charcoal dated from the survey (Table 1; Fig. 5). Due to the strong stylistic differences in ceramics (see below) between layer 5 and 4 , the contexts from layer 5 have been considered as part of a first period of occupation; at the moment, no direct dates are available for layer 3 , and contexts from layer 4 and 3 have been considered together as part of period $2 / 3$ in the analysis below. Based on the limited evidence from calibrated dates, we suggest that the earlier period falls sometime between 750 and $450 \mathrm{BC}$, while the Layer 4 of the later phase falls between ca. $500 \mathrm{BC}$ and $390 \mathrm{BC}$ (Fig. 5).

\section{Site description and material culture}

\section{Features}

Thirty-five ash pits, 4 dwellings, 2 activity floors, 5 jicao "wall foundations" (most likely dwellings of which limits could not be distinguished), and 1 hearth were excavated during the 2017 campaign. Earlier houses cut into the bedrock; these were mostly oval in shape with deep foundations and local archaeologists hypothesised each had a closed pavilion structure. Later houses differ by having a mostly rectangular perimeter with a clear set of postholes along each side, characteristic of wattle and daub structures. Postholes were also found inside the so-called jicao features. Finally, 5 hedao (Chinese for river) fluvial contexts were also found; these 


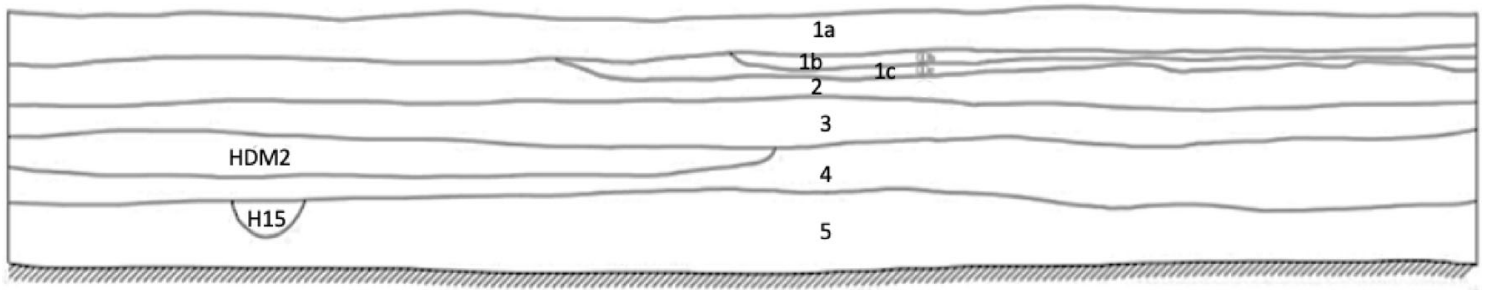

Fig. 4 Trench TN1E2 north wall profile section showing stratigraphy and cultural layers individuated at Dayingzhuang. Provided by Li Xiaorui

are deposits within the vestiges of an ancient riverbed, which has been identified as the pre-Han riverbed of the modern Tanglang, now flowing just outside the excavation area (see Fig. 3).

\section{Ceramics}

Pottery vessels found at Dayingzhuang include $f u$ cauldrons, bo bowls, guan jars, high neck guan jars, and pen plates (Fig. 6). These are characterised by coarse, reddish or greyish temper, with numerous rice husk inclusions trapped in the temper. The decorations are characterised by incised wave (shuibowen 水波纹), comb (zhiwen 栉纹), bow-string (xianwen 线纹), and corded patterns (shengwen 绳纹), which are characteristic of Dian ceramics. According to stratigraphic and ceramic typology, there have been distinguished at least three cultural phases:

- $\quad$ Early phase, corresponding to layer 5; ceramic remains are mostly of coarse grey temper and show a high presence of incised decoration. Vessel assemblage is dominated by guan jars, some with pouring sprouts. Oval, pavilion-type dwellings.

- Middle phase, corresponding to layer 4; appearance of coarse, red temper pottery and decline of grey temper, vessel assemblage dominated by bo bowls. Appearance of wattle and daub type dwellings.
- Late phase, corresponding to layer 3; vessel assemblage dominated by incensed circles (tongxinyuan 同心圆纹) decorated pen plates, bo bowls decrease.

\section{Stone and other implements}

Stone tools found at Dayingzhuang include polished $f u$ axes, ben adzes, and bing-round stone fragments, grindstones, etc. Bone and shell implements were also found, including needles, pins, and scrapers. Finally, some processed agate stone fragments and cowrie shells have been unearthed. The cowrie shells showed holes in their upper extremity, indicating they might have had an ornamental function.

\section{Metal objects}

A dagger (Fig. 7), a plain, wide and flat bracelet, and some metal chips were recovered during the 2017 excavation; metallurgical slags were also reported during the 2010 survey (YPICRA et al. 2015). The limited occurrence of bronze objects at the site of Dayingzhuang is not surprising as Dian bronzes are in fact mostly associated with (wealthy) burials, such as those at Shizhaishan, and generally found in higher quantities in cemeteries, not so frequently found at settlement sites.
Table 1 Radiocarbon dates from Dayingzhuang, indicating context of provenance, material dated, and lab code (YPICRA et al. 2015; Dal Martello 2020). From Dal Martello 2020

\begin{tabular}{lllll}
\hline Context & Material & Lab code & Cal. Date BP & $\begin{array}{l}95.40 \% \text { (Bayesian } \\
\text { model agreement index) }\end{array}$ \\
\hline $\begin{array}{l}\text { 2010 survey } \\
\text { 2017 excavation }\end{array}$ & Unidentified charcoal & Beta-312946 & $\mathrm{n} / \mathrm{a}$ & $780-550$ cal. BC \\
$\begin{array}{l}\text { Layer 2 (modern) } \\
\text { Layer 4 }\end{array}$ & Wheat grain & Beta-501549 & $100 \pm 30$ & 18th or nineteenth century AD \\
Layer 5 & Wheat grain & Beta-501550 & $2380 \pm 30$ & 522-393 cal. BC $(\mathrm{A}=108.1 \%)$ \\
& Wheat grain & Beta-501549 & $2430 \pm 30$ & $746-410$ cal. BC $(\mathrm{A}=102.2 \%)$ \\
\hline
\end{tabular}




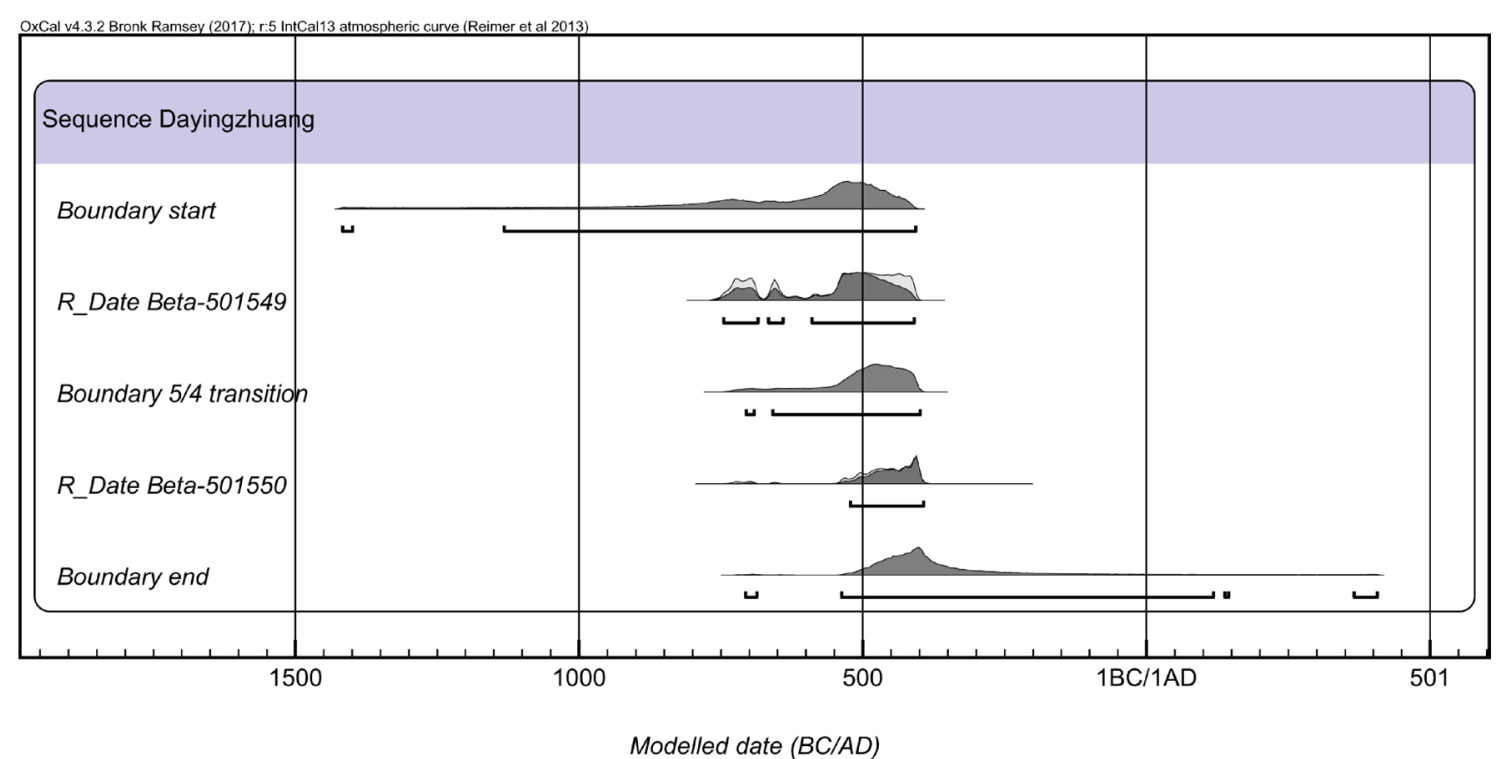

Fig. 5 Bayesian model of the calibrated radiocarbon dates from the 2017 excavation at Dayingzhuang. Made with Oxcal v.4.3.2 (Bronk Ramsey, 2017)

\section{Faunal remains}

Numerous bone tools have been found, including remains of pig, cattle, horse, deer, and fish, but no systematic zooarchaeological analysis has been undertaken on these remains yet. The gastropod species Margarya melanioides, a large edible aquatic snail, constitutes the majority of the shell remains found in the mound layers (YPICRA et al. 2015).

\section{Materials and methods}

\section{Macro-botanical remains}

Over 130 archaeobotanical samples were collected for flotation from each feature across the whole excavation area of the site; from cultural layers in trench TN2E2 (the southwestern $10 \mathrm{x} 10 \mathrm{~m}^{2}$ trench, ${ }^{1}$ and additional cultural layers samples were collected at the cross of the four $10 \times 10 \mathrm{~m}^{2}$ trenches, and labelled GJZ (guanjianzhu 关键柱 meaning “control column”), followed by the layer number. Each sample had a bulk soil volume of $20 \mathrm{~L}$. All samples were manually floated at the site during excavation with the use of a bucket, and the float was collected with a 0.3 -mm mesh into a cotton cloth bag, finally dried naturally in the shade.

All samples collected were scanned at the Yunnan Province Institute of Cultural Relics and ArchaeologyArchaeobotany Laboratory under a Leica low power binocular microscope at magnification up to X40. Of the scanned

\footnotetext{
${ }^{1}$ In trench TN2E2, a total of 5 multiple samples for each individual layer were collected, one at each corner of the trench (S1-4), and one (S5) in the middle, respectively. These were individually sorted, and the results from multiple samples from the same layer were merged before performing quantitative analyses.
}

samples, 32 appeared particularly rich in archaeobotanical remains and were therefore selected to be fully analysed at the UCL-Institute of Archaeology-Archaeobotany Laboratory. The selected samples covered a complete sequence top to bottom, including samples from layer 2 to layer 5, and associated features. However, AMS radiocarbon dating on wheat grains from layer 2 furnished a modern date (see above), therefore contexts corresponding to this layer have been excluded, and a total of 30 samples, corresponding to contexts from layers 3 to 5 , are presented here.

\section{Phytolith remains}

Phytoliths samples were collected vertically every $10 \mathrm{~cm}$ from the GZJ column without performing sieving or any other kind of soil processing; each sample was put into a plastic bag and let dry in the shade. About $10 \mathrm{~g}$ of soil per each sample was brought back to UCL. $12^{2}$ individual samples were selected to be processed and analysed). Even numbers between samples \#16 and \#34 (excluding \#28) were selected. Samples \#3 and \#10 were also selected to provide a modern vegetation baseline (Table 3 below). Laboratory extraction was carried out at the UCL Institute of Archaeology-Phytoliths Laboratory following an adaptation of the protocols of A. M. Rosen (1999; see $\mathrm{S} 1$ ).

Each phytolith slide was examined with the use of a biological binocular microscope with magnifications up to $400 \times$. Phytoliths were counted to reach a minimum of 300 single cells and 150 multi-cells counts respectively per each slide.

\footnotetext{
${ }^{2}$ Originally, sample \#12 (from layer 3) was also processed to slide, but after mounting to slide was revealed to be too badly mounted to be successfully analysed and was thus discarded,
} 

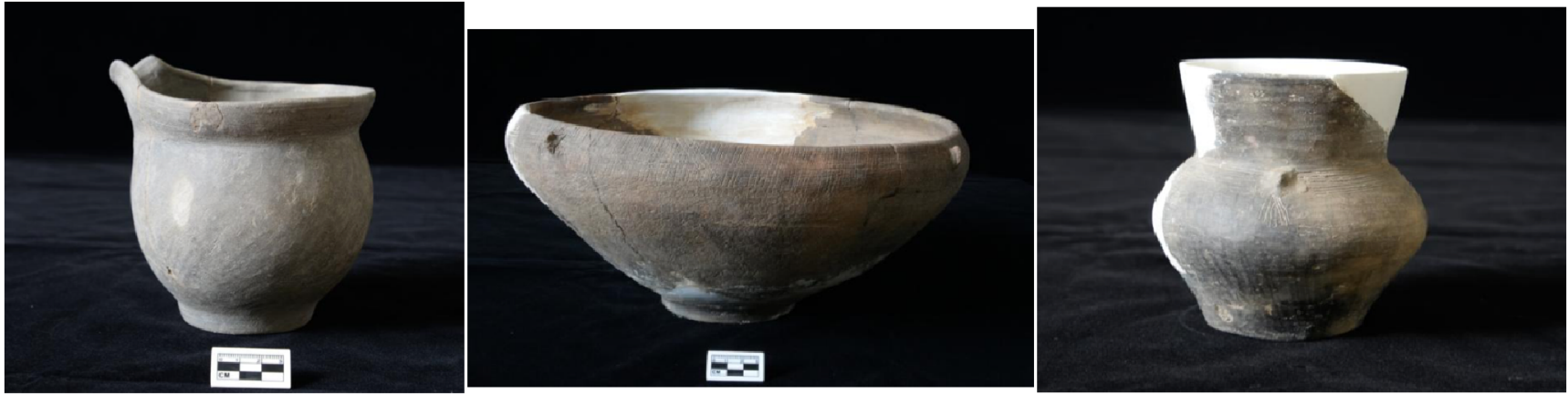

Fig. 6 Ceramic vessels unearthed at the site of Dayingzhuang. Left to right: guan jar with spout; basin; high neck guan jar. Photos by Li Xiaorui

Phytoliths were classified according to the morphotype divisions outlined in Piperno (2006) and Madella et al. (2005).

\section{Results}

\section{Macro-botanical remains}

\section{General features of the assemblage and key economic taxa}

Only charred archaeobotanical remains were recovered from the Dayingzhuang samples, but not in great quantity, as evident by the low density of items/l, with negligible difference between the two periods (Table 2). This is most probably due to modern agriculture and erosion activity from the nearby Tanglang River. A total number of 1070 identified remains, belonging to 14 families, and over 20 individual species, have been recovered from the samples analysed (Table 2).

Identifiable remains were categorised in the following groups:

- Cereals, including wheat-Triticum aestivum, barleyHordeum vulgare, rice-Oryza sativa, Chinese millets, both foxtail millet-Setaria italica and broomcorn milletPanicum miliaceum, and indeterminate millets;

- Other possible cultigens (including Chenopodium, nuts, and fruits and other wild species);

- Seeds of likely field weed species.

\section{Cereal crops}

Five different species of cereal crops were recovered from the Dayingzhuang samples, including Chinese domesticated rice (Oryza sativa) and millets (Setaria italica and Panicum miliaceum), and western domesticates, wheat (Triticum aestivum) and hulled barley (Hordeum vulgare, Fig. 16: 1-6). Charring normally removes any trace of the barley hulls, but grain shape surface features allow hulled barley to be identified in this case. Naked barley grains have a rounded cross section and fine transverse wrinkling on well-preserved grains, whereas hulled barley are angular in cross-section with longitudinal ridges on the surface. The presence of asymmetric grains indicates the presence of six-row hulled barley (Hordeum vulgare subsp. vulgare, syn. H. hexastichum L.). Cereals altogether constitute c. $86 \%$ of the total identified remains for period 1 ; but decrease to only c. $28 \%$ for period $2 / 3$ (Fig. 8 ). All other

Fig. 7 Metal dagger unearthed at the site of Dayingzhuang. Photo by Li Xiaorui

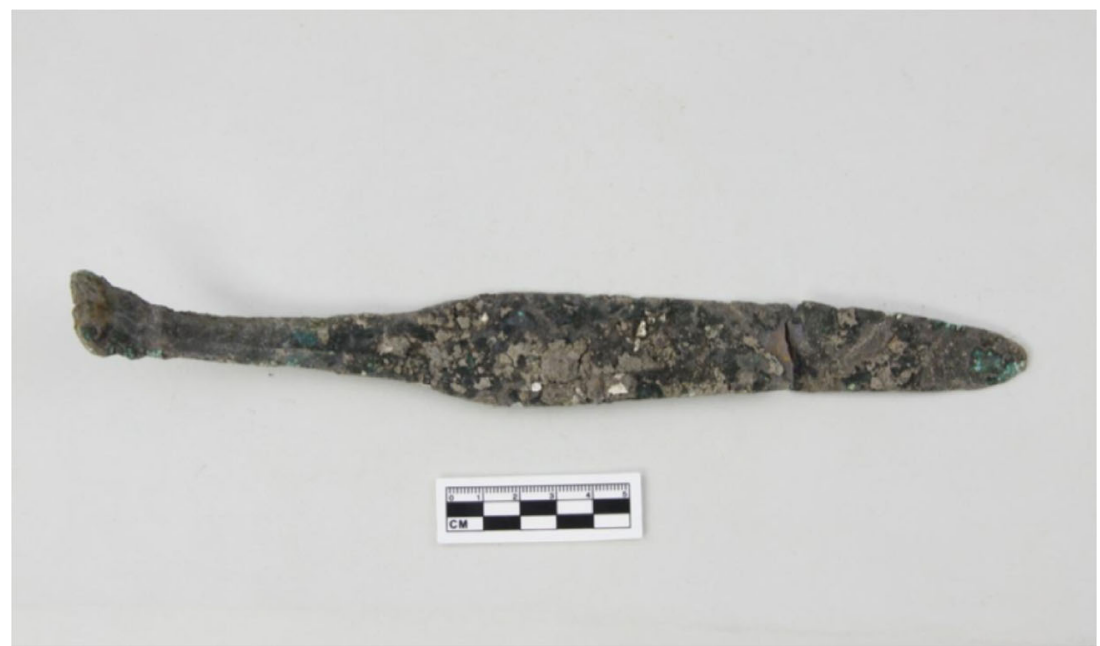


Table 2 Summary of flotation samples and plant macro-botanical remains by period and context type

\begin{tabular}{|c|c|c|}
\hline & Period 1- Layer 5750-405 cal. BC & Period 2/3- Layer 4/3727-393 cal. BC \\
\hline Volume floated (litres) & 360 & 380 \\
\hline No. of samples & 16 & 14 \\
\hline Cultural layers & 4 & 2 \\
\hline Ash pits & 7 & 8 \\
\hline Houses & 3 & 4 \\
\hline Hedao & 2 & 0 \\
\hline No. of identified species & 19 & 16 \\
\hline \multicolumn{3}{|l|}{ Cereals } \\
\hline Triticum aestivum- wheat grains & 243 & 65 \\
\hline Triticum aestivum- grain fragments & 98 & 8 \\
\hline Triticum aestivum- rachises & - & 1 \\
\hline Triticum aestivum- immature grains & - & 1 \\
\hline Oryza sativa- rice grains and embryos & 32 & 21 \\
\hline Oryza sativa- rice grain fragments & 41 & 15 \\
\hline Oryza sativa- spikelet bases & 23 & - \\
\hline Oryza sativa- immature grains & 7 & - \\
\hline Setaria italica- foxtail millet grains & 16 & 17 \\
\hline Setaria italica- foxtail millet immature grains & 3 & 1 \\
\hline Panicum miliaceum- broomcorn millet grains & 18 & 8 \\
\hline Indet millet fragm. & 2 & - \\
\hline Hordeum vulgare- barley grains & 1 & 5 \\
\hline Hordeum vulgare- rachis & - & 1 \\
\hline Hordeum vulgare- immature grains & - & 1 \\
\hline \multicolumn{3}{|l|}{ Other possible cultigens } \\
\hline Chenopodium sp. & 41 & 312 \\
\hline Euryale ferox-foxnut fragments & 8 & 35 \\
\hline cf. Castanea sp.- chestnut & 1 & - \\
\hline Indet. Acorn & 3 & 3 \\
\hline Zanthoxylum sp.- Sichuan pepper & - & 3 \\
\hline \multicolumn{3}{|l|}{ Seeds of field weeds } \\
\hline \multicolumn{3}{|l|}{ Grasses \& seeds of dryland cultivation } \\
\hline Pennisetum sp. & 2 & - \\
\hline Vicia sp. & 2 & 1 \\
\hline Fabaceae- indeterminate & 2 & - \\
\hline Solanum sp. & 1 & - \\
\hline Portulaca sp. & - & 2 \\
\hline Euphorbiaceae- indet. & - & 1 \\
\hline \multicolumn{3}{|l|}{ Sedges- \&seeds of wetland cultivation } \\
\hline Schoenoplectus sp. & - & 1 \\
\hline Rumex sp. & 2 & 3 \\
\hline Alisma sp. & 1 & - \\
\hline \multicolumn{3}{|c|}{ Other weeds- seeds of both dry and wetland cultivation } \\
\hline Echinochloa sp. & 1 & 1 \\
\hline Apiaceae- indet. & 1 & - \\
\hline \multicolumn{3}{|l|}{ Wild species } \\
\hline Ilex sp. & - & 1 \\
\hline Rosaceae- indet. & 3 & - \\
\hline Indeterminate small seeds & 6 & 5 \\
\hline Total macro-remains & 558 & 512 \\
\hline Density of items/l & 1.55 & 1.28 \\
\hline
\end{tabular}

cereal species except for barley, decrease during the later period of occupation. With the exclusion of wheat, frequency and ubiquity index for cereals show a strong correlation (Fig. 8).

The very low ubiquity of wheat remains from period 1 is due to the high concentration of wheat remains from fluvial context Hedao 1, where 307 out of 416 total wheat remains (including whole grains, immature grains, grain fragments and rachis) were found (Fig. 9). This type of context is not present in period 2/3 (see S2).

\section{Wheat and barley}

Wheat and barley have been found in c. $80 \%$ of the samples analysed, and account for c. $40 \%$ of the total archaeobotanical remains from the Dayingzhuang samples. However, barley only constitutes c. $2 \%$ of the total identified remains. Chronologically, wheat remains constitute the main species recovered during period 1 , but decrease sharply in period $2 / 3$; barley instead increases a little in period $2 / 3$ (Fig. 8). Density of wheat remains per litre floated is $0.63 / \mathrm{L}$. 

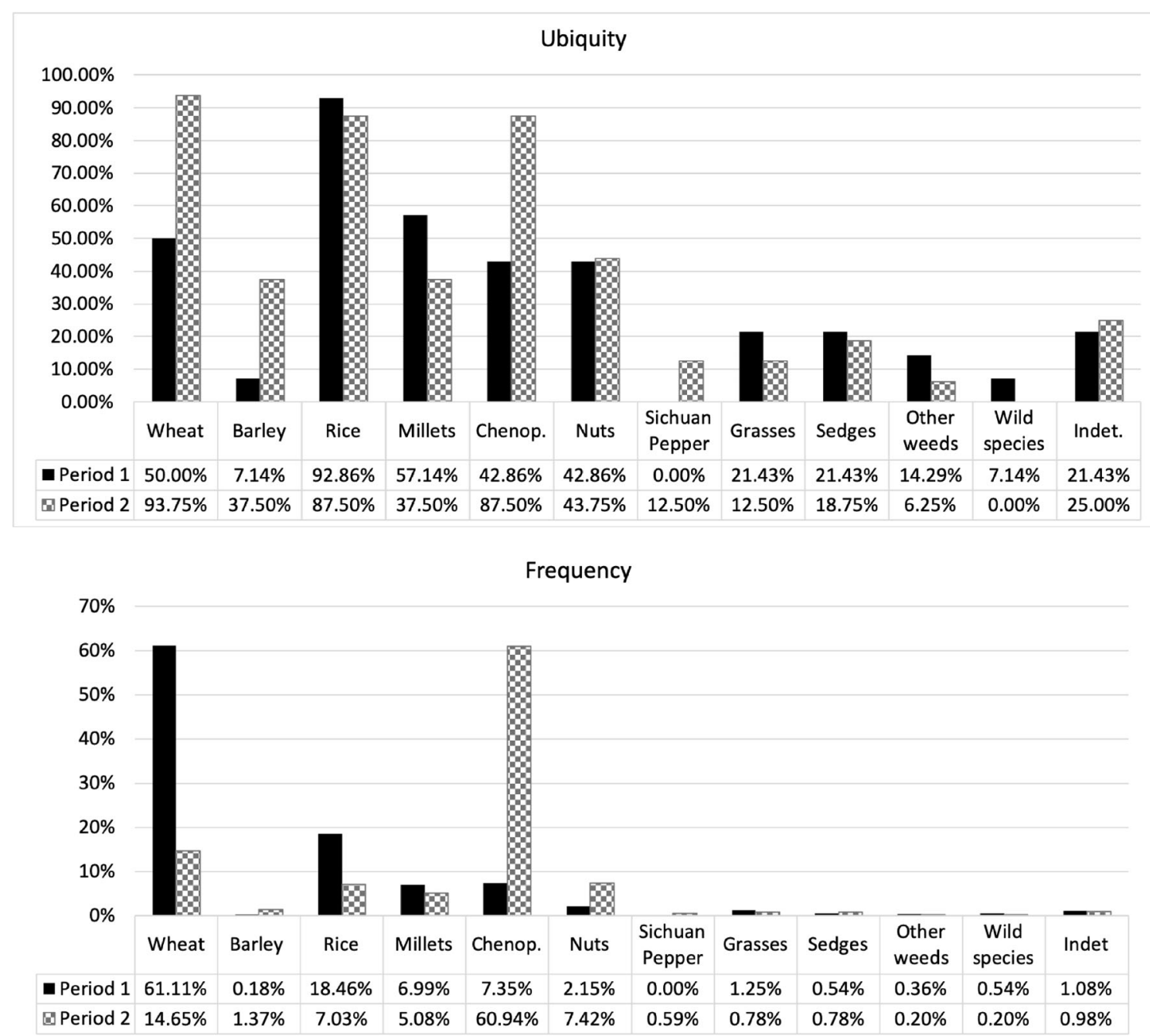

Fig. 8 Ubiquity (top) and frequency (bottom) index of archaeobotanical remains at Dayingzhuang

Ninety grains of wheat were measured (Table S3), and these were on average $4.06 \mathrm{~mm}$ long, with a standard deviation of $0.43 ; 2.95 \mathrm{~mm}$ wide (standard deviation of 0.38 ); and $2.53 \mathrm{~mm}$ thick (standard deviation of 0.30 ). Wheat $\mathrm{L} /$ $\mathrm{W}$ at Dayingzhuang was $1.38 \mathrm{~mm}$, with a standard deviation of $0.14 \mathrm{~mm}$ (Fig. 10; Table S3). We compared these to
Fig. 9 Cereal remains context analysis at Dayingzhuang, with indication of absolute counts. Hedao refers to alluvial/river adjacent contexts

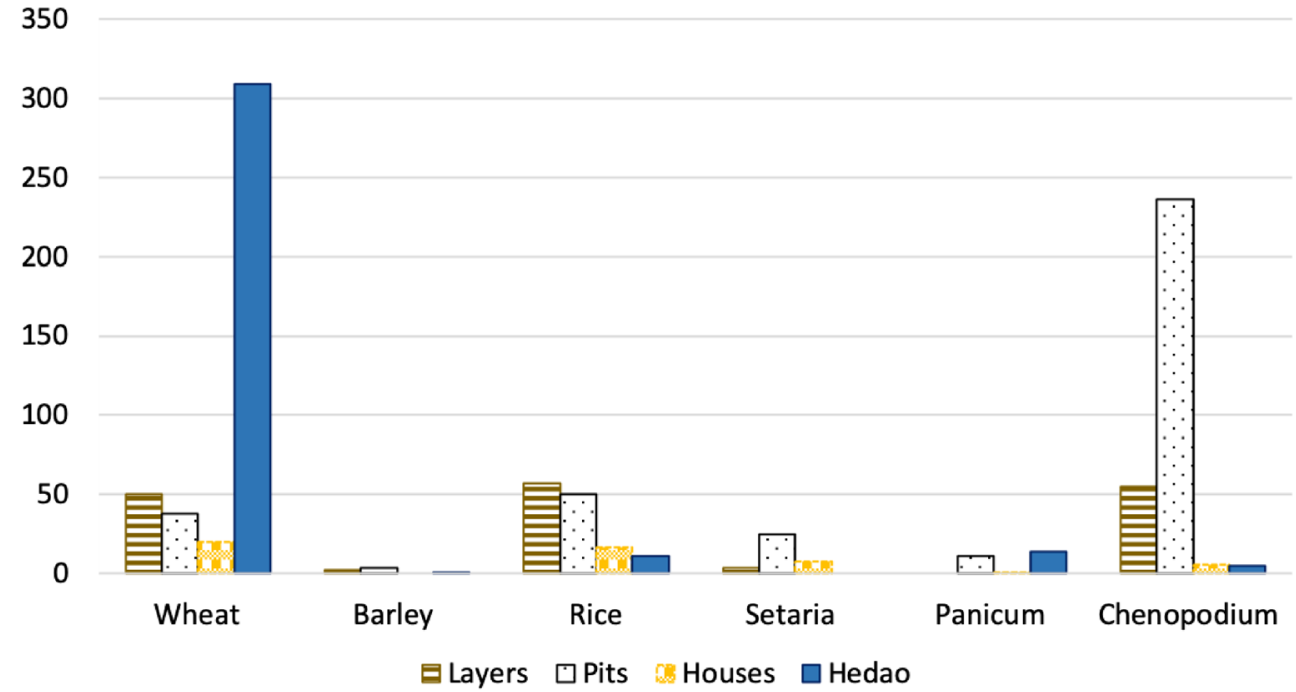




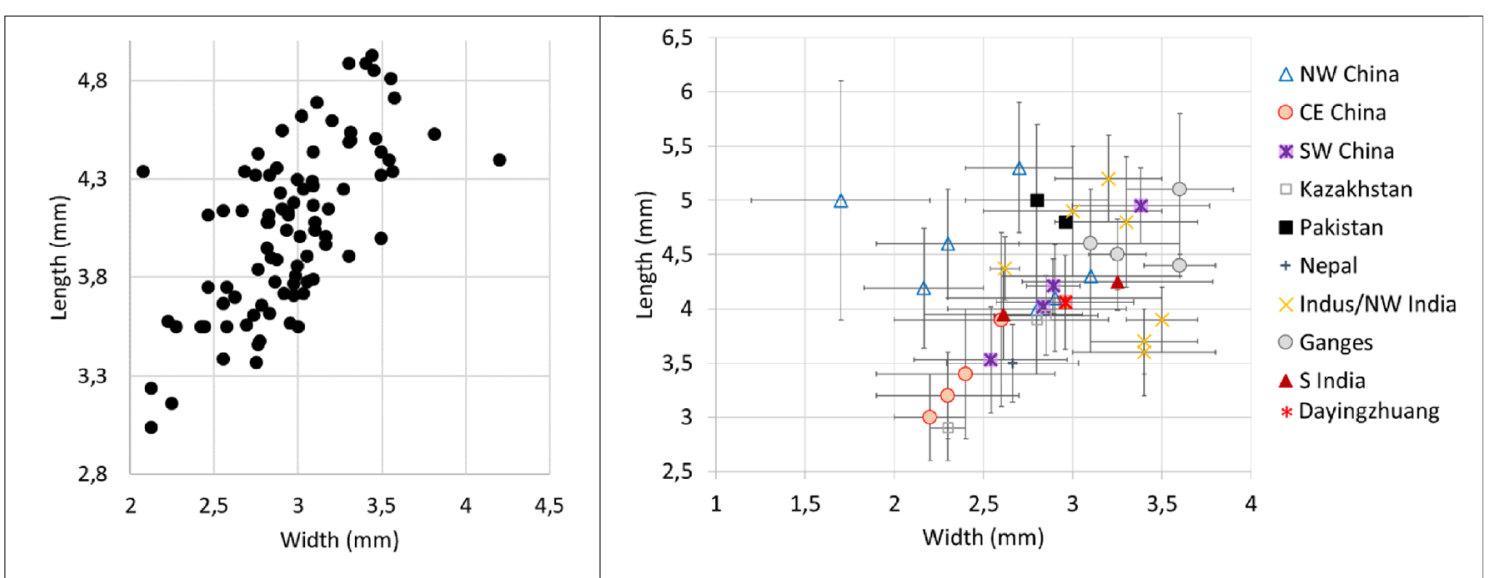

Fig. 10 (Left) Scatterplot of L/W ratio of Dayingzhuang wheat (Triticum aestivum) grains. (Right) Averages L/W ratio from published wheat measurements dataset from countries in Asia, red star indicates Dayingzhuang (data from Dal Martello 2020; Xue 2010; Jin 2013; Li and Liu 2016;
Zhou et al. 2020; Spengler et al. 2014; Spengler et al. 2013; Asouti and Fuller 2008; Fuller 2000; Saraswat 2004; Vishnu-Mittre 1982; Chanchala 2002; Pokharia et al. 2011) a set of published measurements from across South, Central and East Asia (for a map of sites see Fig. 11). Dayingzhuang wheat falls amidst wheat from other sites in Southwest China, some assemblages from northwest China and from Central Asia (Kazakhstan), and further away from published assemblages in northern India or
Central/Eastern China. Only 4 grains of barley from the Dayingzhuang samples were well preserved enough to be measured, and these were on average $5.13 \mathrm{~mm}$ long, $2.61 \mathrm{~mm}$ wide, and $2.12 \mathrm{~mm}$ thick; average $\mathrm{L} / \mathrm{W}$ was $1.96 \mathrm{~mm}$, with a standard deviation of $0.21 \mathrm{~mm}$ (Fig. 12; Table S3).

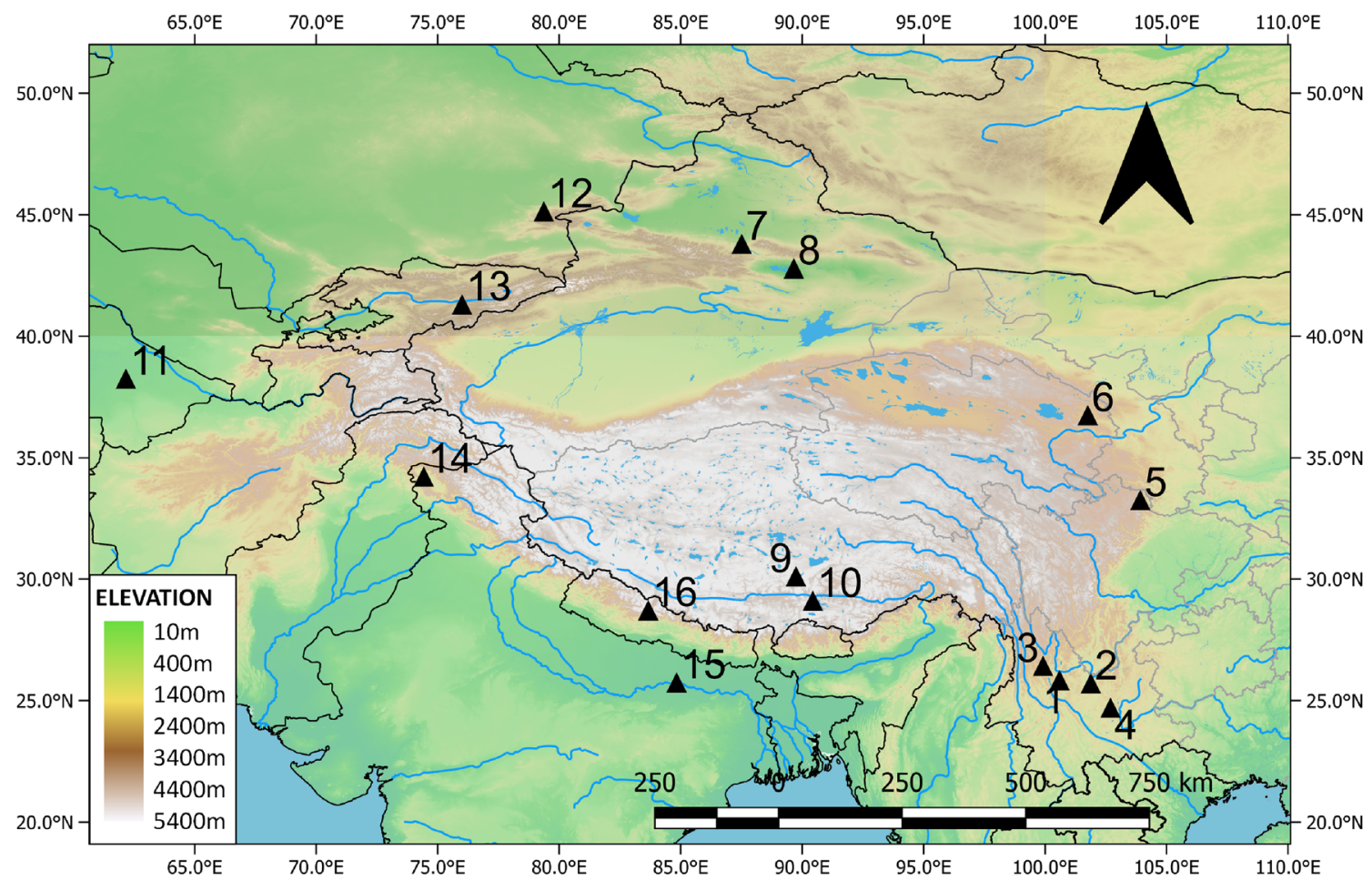

Fig. 11 Map showing sites mentioned in the discussion, sites 3-16 report the presence of wheat and/or barley grains, measurements from these sites are plotted for comparison to those from Dayingzhuang (Figs 10, 12). 1 Baiyangcun; 2 Dadunzi; 3 Haimenkou; 4 Shangxihe; 5 A'shaonao; 6
Xiasunjiazhai; 7 Sidaogou; 8 Yanghai; 9 Khog gzung; 10 Bangtangbu; 11 Ojakly; 12 Tasbas; 13 Aigyrchal-2; 14 Kanispur; 15 Chirand; 16 Chokhopani. Made with QGIS 3.10.10 


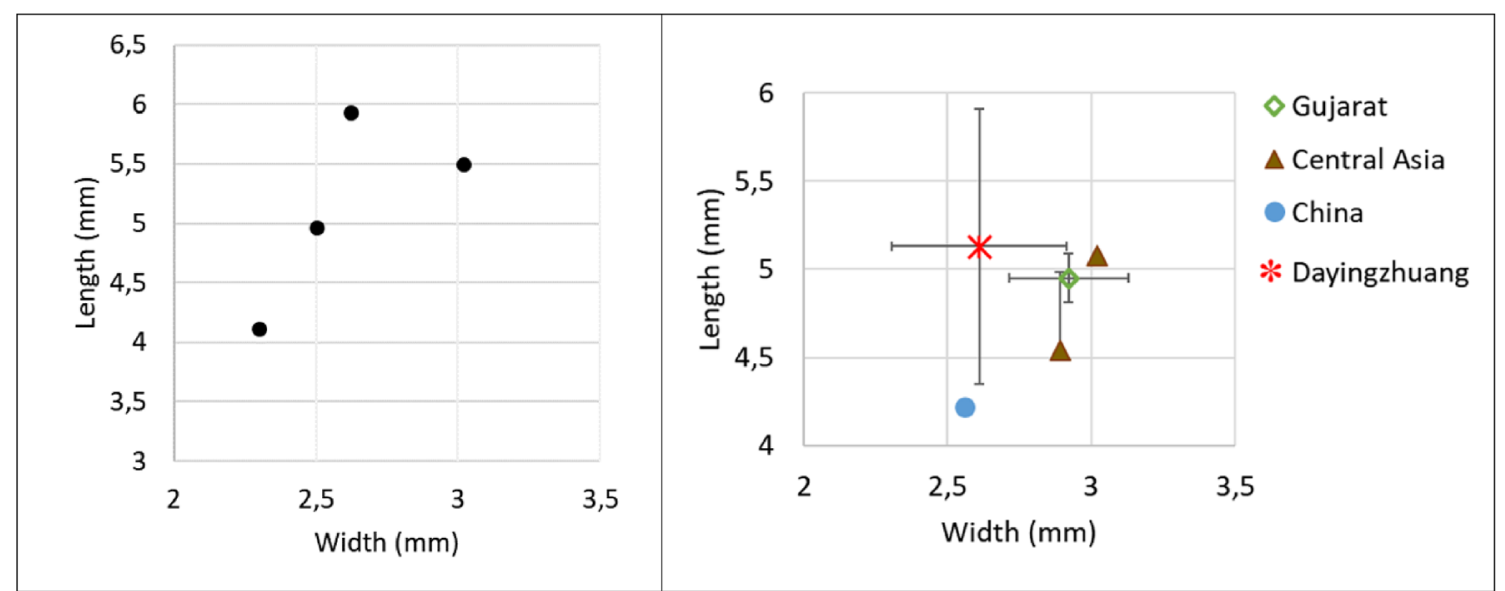

Fig. 12 (Left) Scatterplot of L/W ratio of Dayingzhuang barley (Hordeum vulgare) grains. (Right) Averages L/W ratio from published barley measurements dataset from countries in Asia, red star indicates Dayingzhuang (data from Pokharia et al. 2011; Spengler et al. 2013, 2014; Zhou et al. 2020)

\section{Rice}

Rice remains have been found in $90 \%$ of the samples analysed at Dayingzhuang, however they only constitute c. $13 \%$ of the total identified remains. Rice remains constitute c. $18 \%$ of the total identified remains for period 1 , but decrease to only $7 \%$ for period $2 / 3$, even though the ubiquity of rice remains for both periods is quite high. Rice density is $0.17 / \mathrm{L}$. A total of 21 rice grains were measured, and these were on average $4.71 \mathrm{~mm}$ long, with standard deviation of $0.52 \mathrm{~mm}$; $2.65 \mathrm{~mm}$ wide, with standard deviation of $0.27 \mathrm{~mm}$; and $2.31 \mathrm{~mm}$ thick, with standard deviation of $0.33 \mathrm{~mm}$ (Table S3). Average L/W was $1.78 \mathrm{~mm}$, with a standard deviation of $0.24 \mathrm{~mm}$ (Fig. 13). According to measurement guidelines set out in Harvey and Fuller (2005) and Castillo et al. (2016), rice L/W of $>2.2$ can be classified as Oryza sativa subsp. indica, and $\mathrm{L} / \mathrm{W}$ of $<2$ is generally considered Oryza sativa subsp. japonica. Among the rice grains measured from Dayingzhuang, only 2 grains measured $>2.2 \mathrm{~mm}$ in L/W, therefore, rice at Dayingzhuang has been classified as Oryza sativa subsp. japonica. Moreover, no morphologically wild rice grains or spikelet bases have been recovered from the Dayingzhuang samples.

\section{Millets}

Foxtail and broomcorn millets were both found in the samples analysed; the two millets account for only c. $6 \%$ of the total identified remains at Dayingzhuang; although foxtail millet is present in slightly higher quantity than broomcorn, the

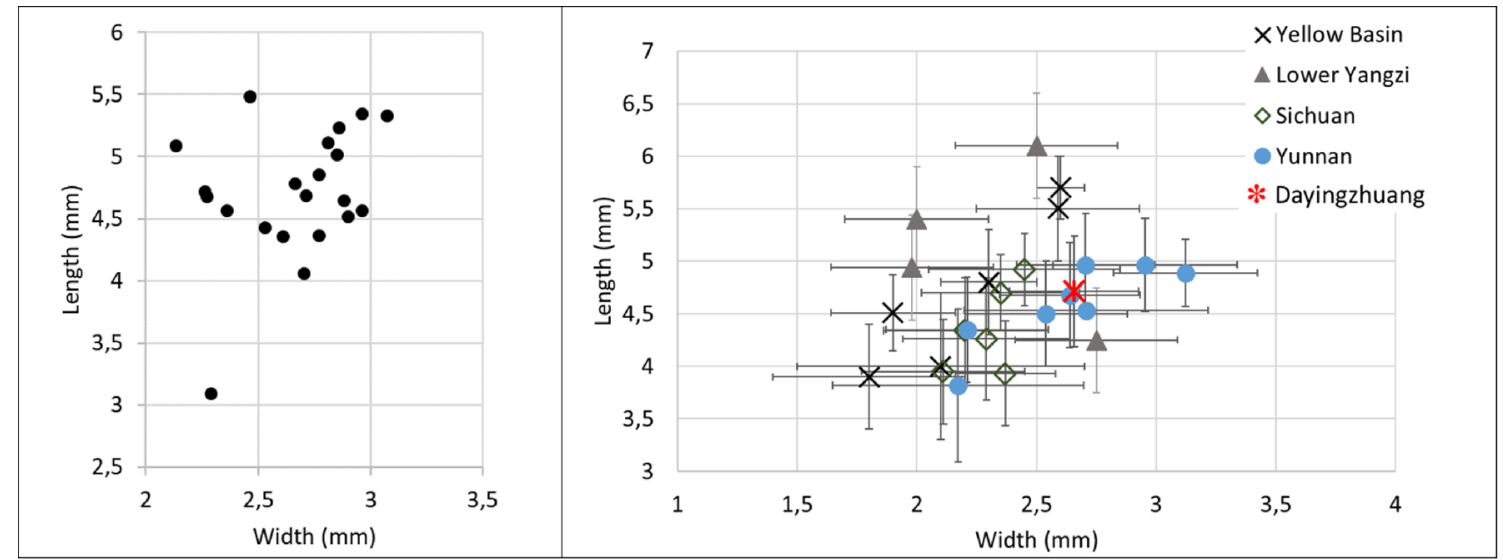

Fig. 13 (Left)Scatterplot of $\mathrm{L} / \mathrm{W}$ ratio of rice (Oryza sativa) grains.(Right) Averages L/W ratio from published rice measurements dataset in China, red star indicates Dayingzhuang (data from Crawford et al. 2006; Tang 1999; Li 1994; Lee and Bestel 2007; Tang et al. 2003; Huang and Zhuang 2000; Zheng et al. 2004; Fuller et al. 2014; Shanghai
Museum 2014; Fuller et al. 2010; Zhao 2003; D’Alpoim et al. 2009; D'Alpoim et al. 2013; Zhao 2011; Yang 2016; Wang 2014; Pei 1998; Zhang and Wang 1999; Liu et al. 2007; Li and Liu 2016; Deng 2016 unpublished). Remade from Dal Martello 2020 


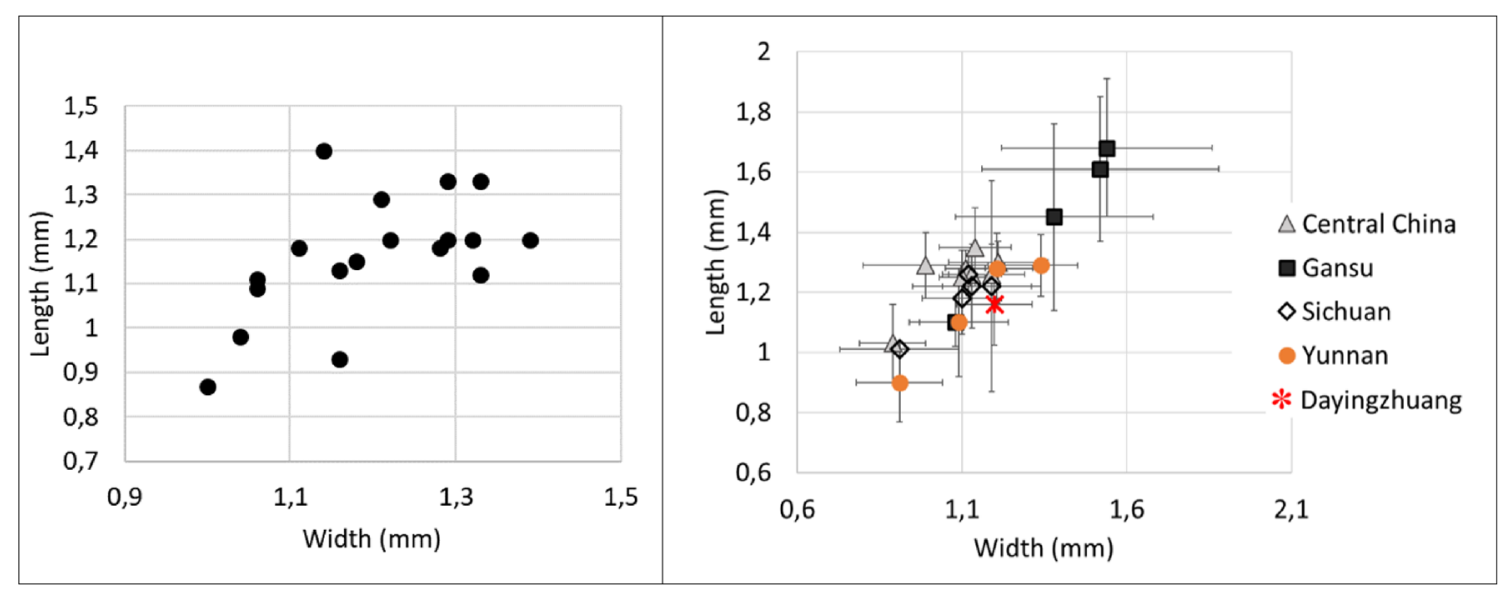

Fig. 14 (Left) Scatterplot of L/W ratio of Dayingzhuang foxtail millet (Setaria italica) grains. (Right) Averages L/W ratio from published Setaria measurements dataset in China, red star indicates Dayingzhuang (data

differences between the two are negligible (see S2). Millet density per litre is 0.8 items $/ \mathrm{L}$.

Eight complete well-preserved grain of foxtail millet were measured, and these were on average $1.16 \mathrm{~mm}$ long (standard deviation of $0.13 \mathrm{~mm}$ ), $1.19 \mathrm{~mm}$ wide (standard deviation of $0.11 \mathrm{~mm}$ ), and $0.9 \mathrm{~mm}$ thick (standard deviation of $0.1 \mathrm{~mm}$ ). The average $\mathrm{L} / \mathrm{W}$ for foxtail millet was $0.97 \mathrm{~mm}$ (standard deviation of $0.10 \mathrm{~mm}$ ); these are comparable to other Neolithic and Bronze Age grains from southwest China (Fig. 14). Fifteen grains of broomcorn millets were measured, furnishing an average length of $1.76 \mathrm{~mm}$ (standard deviation $0.15 \mathrm{~mm}$ ). width $1.73 \mathrm{~mm}$ (standard deviation $0.21 \mathrm{~mm}$ ), and thickness $1.3 \mathrm{~mm}$ (standard deviation $0.21 \mathrm{~mm}$ ). Average L/W was $1.33 \mathrm{~mm}$ (standard deviation $0.21 \mathrm{~mm}$ ). These also compare well with domesticated broomcorn millet identified from elsewhere in China (Fig. 15; see also Table S3; Stevens et al. 2020). from Barton 2009; Yang 2016; Stevens unpublished data). Remade from Dal Martello 2020

\section{Chenopodium}

At Dayingzhuang, Chenopodium grains have been recovered in very high quantity and ubiquity, especially from the $2 / 3$ period of occupation; it is the second most abundant species recovered (Fig. 8; Fig. 16: 12), and the total density of Chenopodium grains per litre is $0.46 / \mathrm{L}$. In the first period of occupation Chenopodium is found mostly in layer contexts; during period $2 / 3$ instead, the species has been recovered from pit contexts, especially $\mathrm{H} 8$ and H11 (see Fig. 9). This trend is similar to that seen for dryland weeds at the site; however, these were recovered in extremely low quantity. Measurements on 28 Chenopodium grains showed average measurements comparable to modern wild Chenopodium (Table S3; Dal Martello 2020). It has been proposed that this species might have been cultivated at the earlier sites of Guiyuanqiao in Sichuan (dated to between c. 3100 and

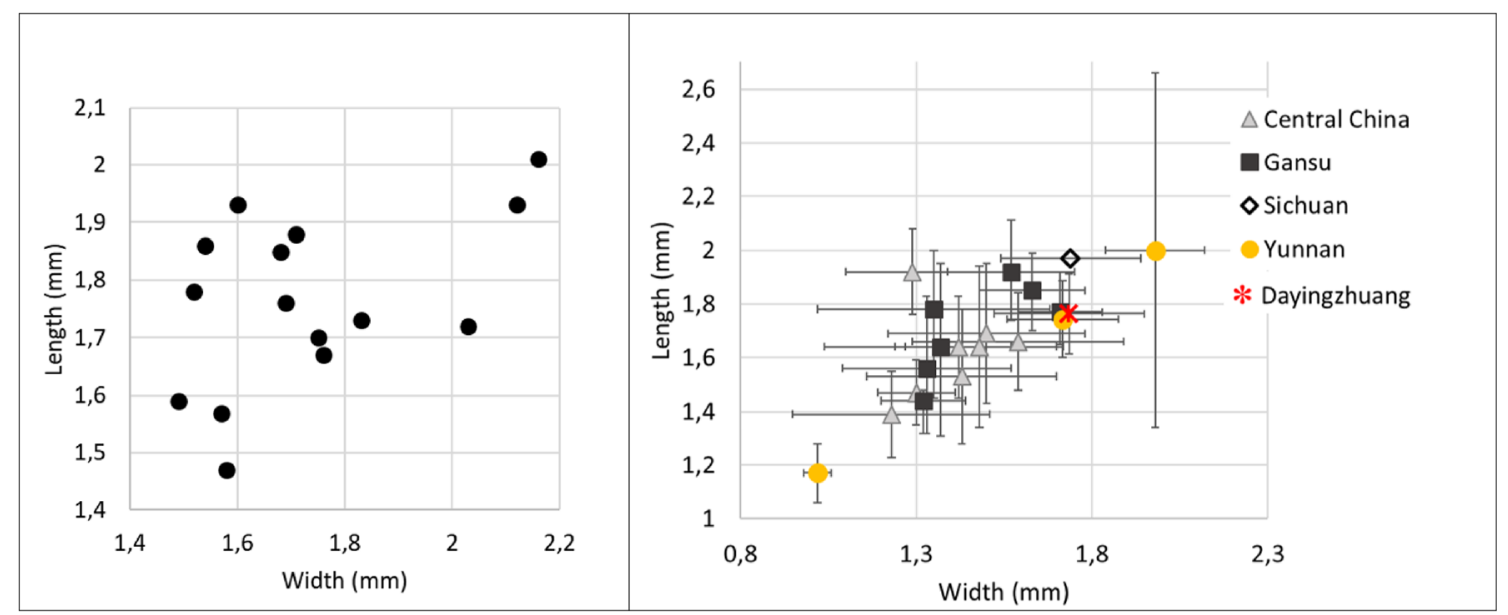

Fig. 15 (Left) Scatterplot of L/W ratio of Dayingzhuang Broomcorn millet (Panicum miliaceum) grains. (Right) Averages L/W ratio from published Panicum measurements dataset in China, red star indicates
Dayingzhuang (data from Barton 2009; Yang 2016; Stevens et al. 2020). Remade from Dal Martello 2020 


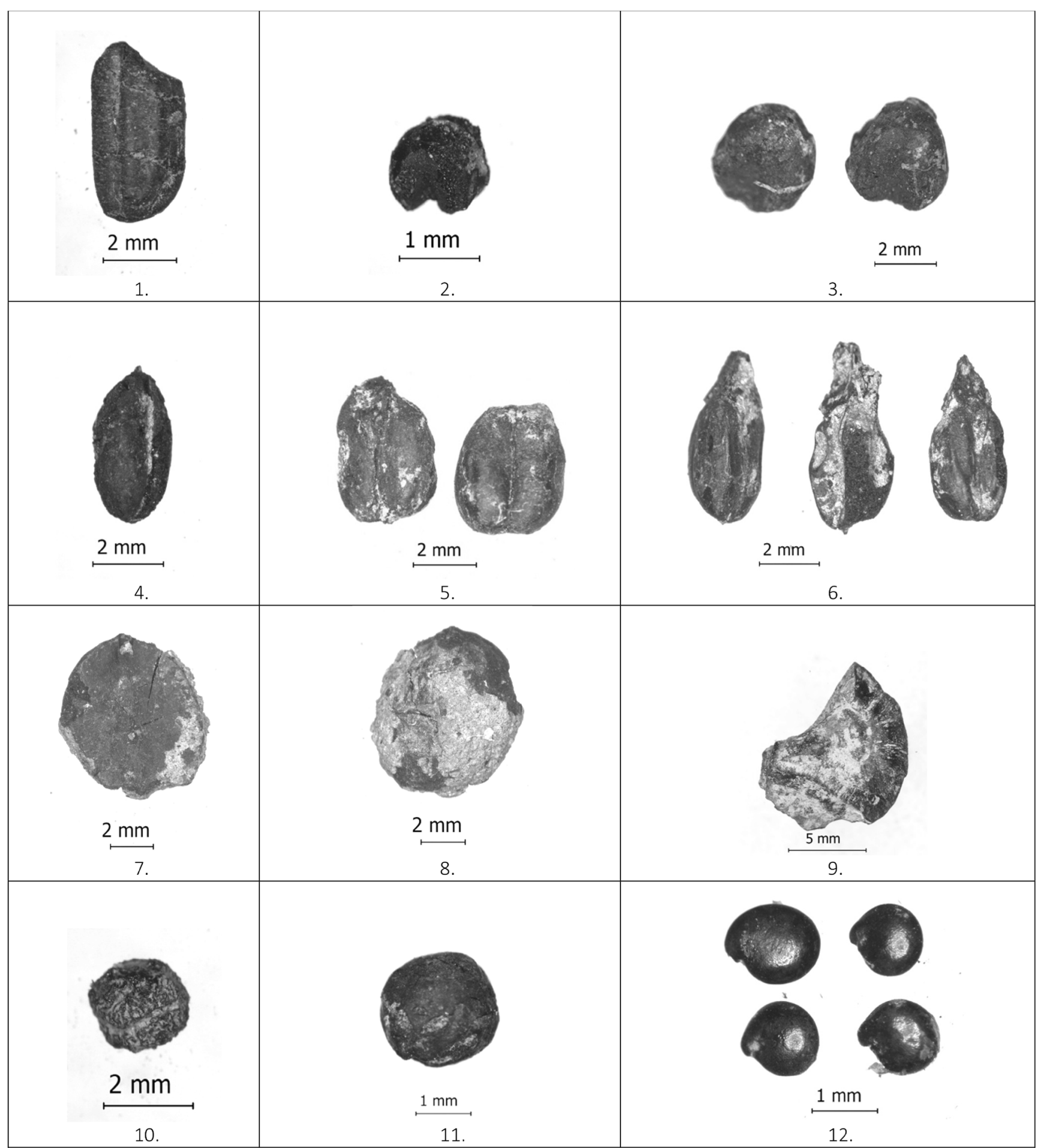

Fig. 16 Photos of macro-botanical remains from Dayingzhuang. 1. Oryza sativa; 2. Setaria italica; 3. Panicum miliaceum; 4. Hordeum vulgare; 5. Triticum aestivum; 6. Triticum aestivum; 7-8., Castanea $\mathrm{cf.}$; 9. Indet.

acorn ; 10. Zanthoxylum sp.; 11. Vicia sp.; 12. Chenopodium sp. From Dal Martello 2020
2000 BC, D'd'Alpoim Guedes and Wan 2015), at Haimenkou, in Northwest Yunnan (dated to between 1600 and $400 \mathrm{BC}$; Xue 2010; Dal Martello 2020), as well as from later sites during the Han Dynasty (Yang and Liu 2009). However, very little archaeological investigation of this species' domestication trajectory has been undertaken so far, with most publications categorising this species as a weed; therefore, until more systematic 
Table 3 Summary of Dayingzhuang phytolith samples, with indication of their original sample number, laboratory sample ID and stratigraphic relation to cultural layers, and percentage weight of phytoliths per each sample. From Dal Martello 2020

\begin{tabular}{llll}
\hline Original sample \# & Lab. Phytolith ID & Corresponding stratigraphy & \% weight \\
\hline 3 & 12 & Modern topsoil & 0.53 \\
10 & 11 & Layer 2 (modern) & 5.86 \\
12 & 10 & Layer 3 (discarded) & $n / a$ \\
16 & 9 & Layer 3 & 13.07 \\
18 & 8 & Layer 4 & 1.24 \\
20 & 7 & Layer 4 & 0.62 \\
22 & 6 & Layer 4 & 1.76 \\
24 & 5 & Layer 4 & 14.8 \\
26 & 4 & Layer 5 & 9.9 \\
30 & 3 & Layer 5 & 0.37 \\
32 & 2 & Layer 5 & 0.38 \\
34 & 1 & Layer 5 & 22.7 \\
\hline
\end{tabular}

analysis is done on more archaeological assemblages, the specific role, if any, Chenopodium had at Dayingzhuang remains unclear.

\section{Other possible cultigens}

Although recovered in very low quantities, other economic species were found at Dayingzhuang (Fig. 16: 7-11), including remains of foxnut (Euryale ferox), chestnut (Castanea sp.), unidentified remains of acorns, Sichuan pepper (Zanthoxylum sp.), unidentified Rosaceae, and Ilex sp. Among these, nut remains are found in about $40 \%$ of the samples analysed. Noteworthy is the find of Zanthoxylum seed, as Southwest China has been indicated as the possible domestication centre for Sichuan pepper. Recently, thanks to the more systematic use of flotation to recover macrobotanical remains during excavations in China, archaeological Zanthoxylum remains have been increasingly reported from sites in Southwest China (Sheng et al. 2020; D'Alpoim Guedes 2013; Li et al. 2016; Yang 2016; Wang 2014).

\section{Seeds of field weed species}

Not many remains of field weed species were recovered from the Dayingzhuang samples, including seeds of dryland field weeds, such as Pennisetum sp., and Vicia sp.; nutlets of wetland field weeds, such as Schoenoplectus sp., and Rumex sp., and a few grains of Echinochloa sp. They altogether account for only $2.15 \%$ of the archaeobotanical assemblage for period 1 , and $1.76 \%$ for period $2 / 3$. The differences between dryland and wetland weed frequency and ubiquity are negligible across different time periods, and their overall very low presence make them not statistically significant for investigating crop ecology at the site. Nevertheless, those taxa present suggest some combination of wet agriculture fields, presumably for rice, and dry cultivation, which might include millets or wheat and barley.

\section{Phytoliths remains: general features}

A total of 11 phytolith samples, covering a complete sequence top to bottom, including 2 samples from modern layers, were analysed (Table 3). The average percentage by weight of phytoliths for the samples analysed was $6.48 \%$; minimum percentage weight was $0.37 \%$, (sample 30 ) and maximum percentage weight was $22.7 \%$ (sample 34 ); however, most of the samples were less than $1 \%$, and only four had percentage weights over $9 \%$ (see Table 3 ).

Monocot single cells were the most abundant phytoliths recovered from the samples analysed, accounting for $70 \%$ of the total single cells. Among the single cells, long cells are the most common type found (smooth, echinate, or dendritic), secondarily rondels and saddles. Among the multi-cell morphotypes, unidentified husk remains and Oryza type husks (especially Oryza double-peak glume cells) are the most abundant type recovered (S4; Fig. 17). Oryza husk phytoliths have been recovered from all samples analysed, and they have been found in especially high quantity in samples \#20, \#18, and \#16, corresponding to layer 4 (period 2/3; Fig. 18). In these samples monocot single cells decrease to c. $8-18 \%$. Further husk phytoliths of the cf. Setaria and cf. Triticum types have been found in 7 samples (Fig. 18).

Other grass taxa recovered from the Dayingzhuang phytoliths include morphotypes belonging to the Pooidae subfamily, attested in samples 30-26 (period 1); and the Chloroideae, Panicoideae, Bambusoideae subfamilies, which are however present in generally lower inputs (Fig. 19); in addition, a few examples of the grass tibre Tritiaceae and the family Cyperaceae were noted. 


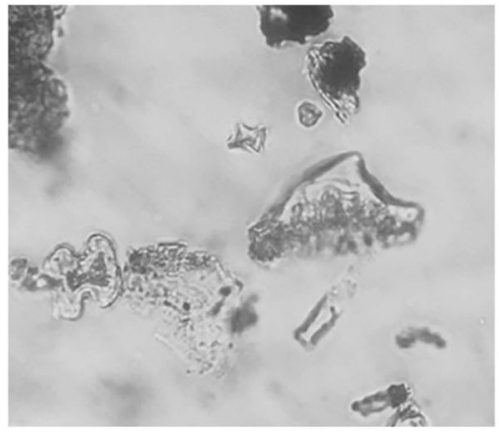

Sample\#22 Cross cell and rice double peaked

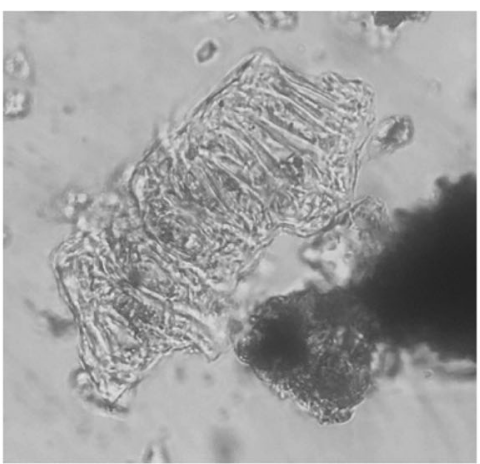

Sample \#22 rice husk

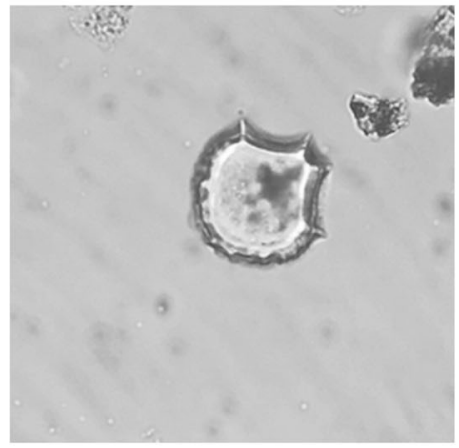

Sample \#18 rice bulliform

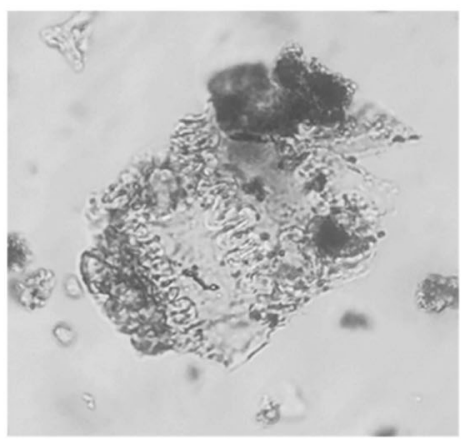

Sample \#22 wheat husk

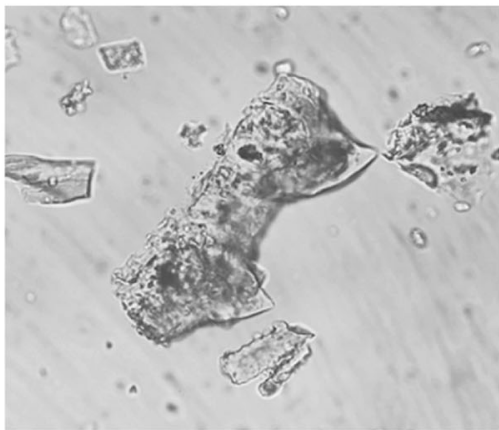

Sample \#18 rice double peaked on husk

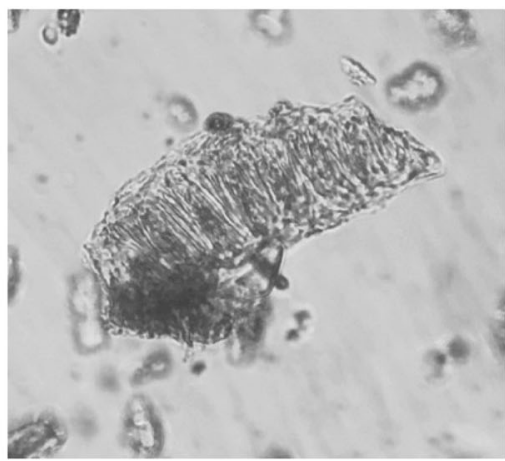

Sample \#22 rice husk

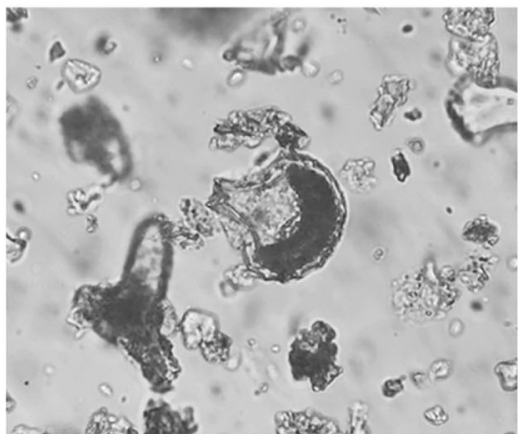

Sample \#18 rice bulliform

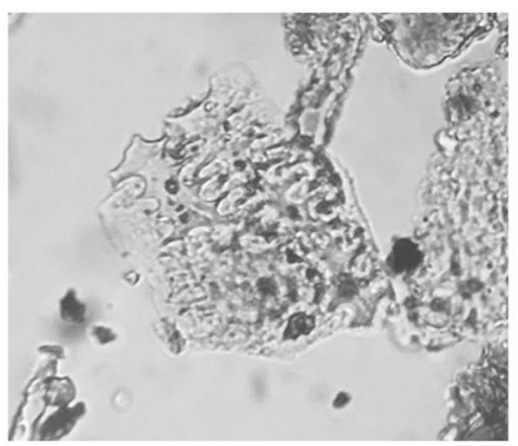

Sample \#18 wheat husk

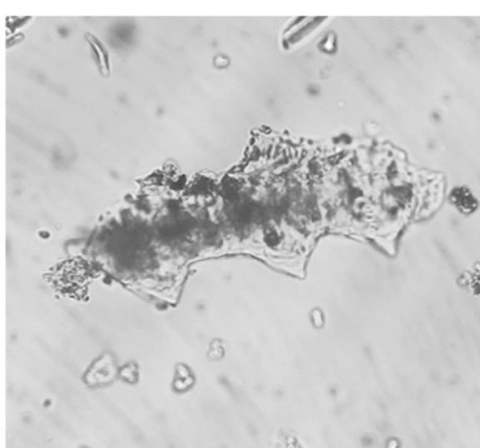

Sample \#18 rice double peaked on husk

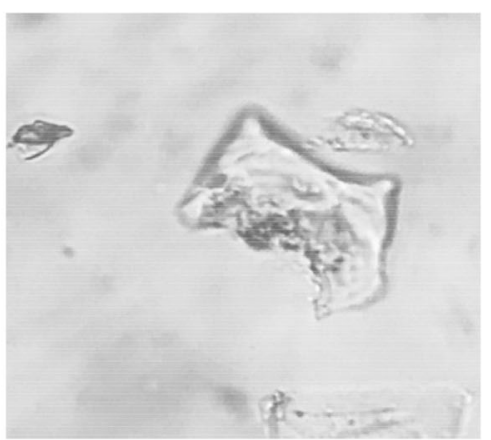

Sample \#24 rice double peaked

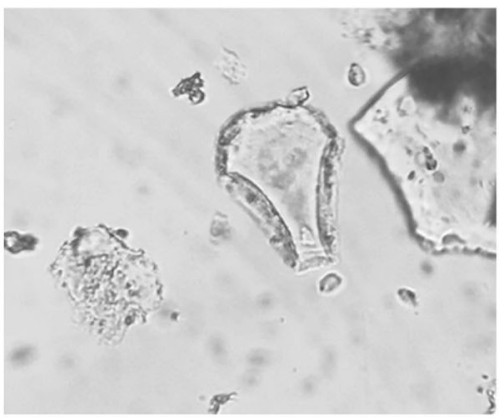

Sample \#16 rice bulliform

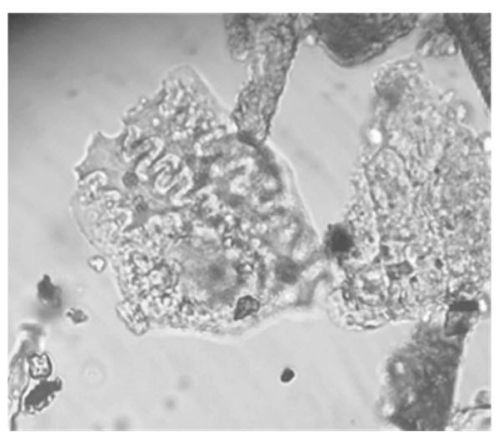

Sample \#18 wheat husk

Fig. 17 Photos of Dayingzhuang phytoliths remains. From Dal Martello 2020 
Fig. 18 Husks remains from phytolith samples at Dayingzhuang

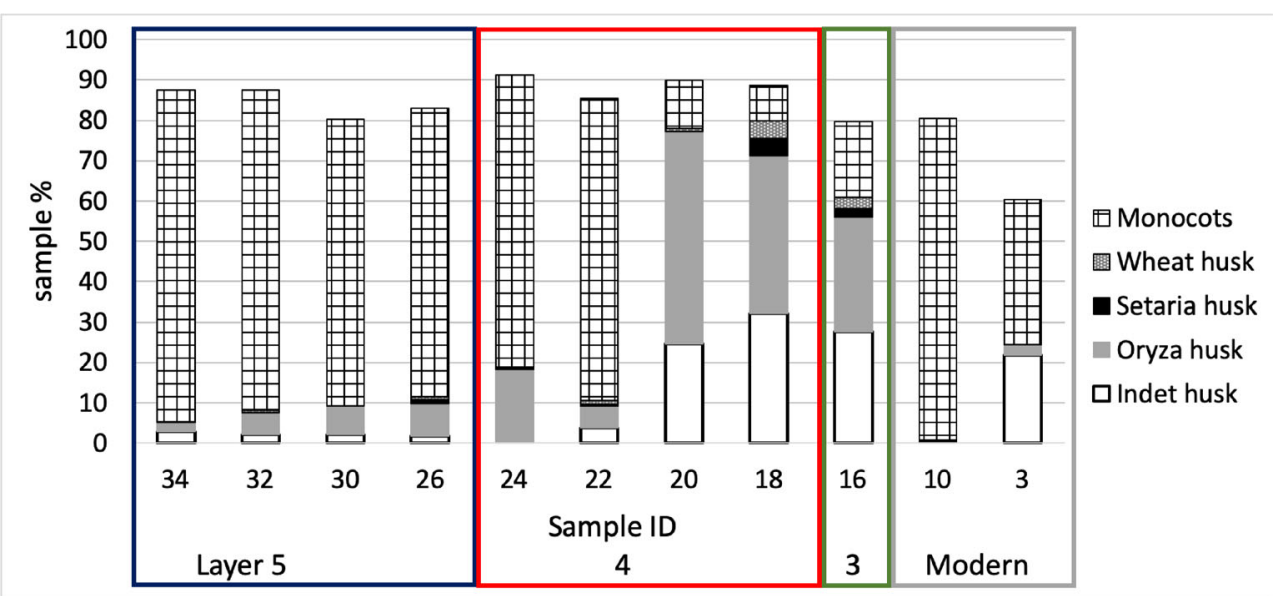

\section{Rice cultivation ecology: inferences from phytoliths}

Madella et al. (2009) and Jenkins et al. (2011) outlined a methodology using the ratio of fixed vs. sensitive grass phytolith morphotypes to investigate irrigation and water usage at archaeological sites. This methodology has successfully been applied to sites in China (i.e. Weisskopf et al. 2015), allowing discussion of crop ecology, especially rice. Fixed morphotypes include short single cells, such as rondels, saddles, bilobates, and crosses; the production of these morphotypes is genetically determined, and specific plant species produce them independently of their water intake. Sensitive morphotypes include long cells, such as long smooth, echinate, and dendritic cells. Differently than short cells, long cell silicification depends on the water intake of the plant during growth, and therefore, if found in higher quantities than fixed morphotypes, they indicate the plant grew under a wet ecological regime (Madella et al. 2009).

Phytoliths from the Dayingzhuang site were classified according the above categories as outlined in Madella et al. (2009), and Weisskopf et al. (2015). While the precise distinction between wet and dry rice in terms of this ratio may be open to some discussion, it is clear that low values indicate dry (rainfed rice). Based on recent Indian work Kingwell-Banham $(2019$ a, b) took as a dry ecology a sensitive: fixed ratio values $<1.5$, whereas Fuller et al. (2016): Fig. 5) took ratios $<1$ as definitely dry, with wet ratios perhaps as low as 1.25 , and semi-wet ratio between 0.9 and 1.2. Kingwell-Banham (2019a, b) also inferred that values $>3$ indicate systematic irrigation, whereas intermediate values (1.5-3) are wet ecologies but not necessarily irrigated. We expect transplanted rice systems to fall in the irrigated range.

The ratios of Dayingzhuang suggest a transition from rainfed to wet and irrigated and/or transplanted rice over the course of the sites occupation (Fig. 20). Despite the high percentage of rice-derived phytoliths, some samples still showed very dry sensitive to fixed morphotype ratios (e.g. samples 20 and 18). The single sample from Layer 3 (no. 16 ), with a ratio of over 3 , indicates a wetter ecology, possibly irrigated rice (Table 4; Figs. 20 and 21). Earlier samples also have drier $\mathrm{S}: \mathrm{F}$ ratio $(<1)$. This suggests that earlier phases may have cultivated rice under direr conditions,
Fig. 19 Relative frequencies of subfamilies phytoliths remains at Dayingzhuang

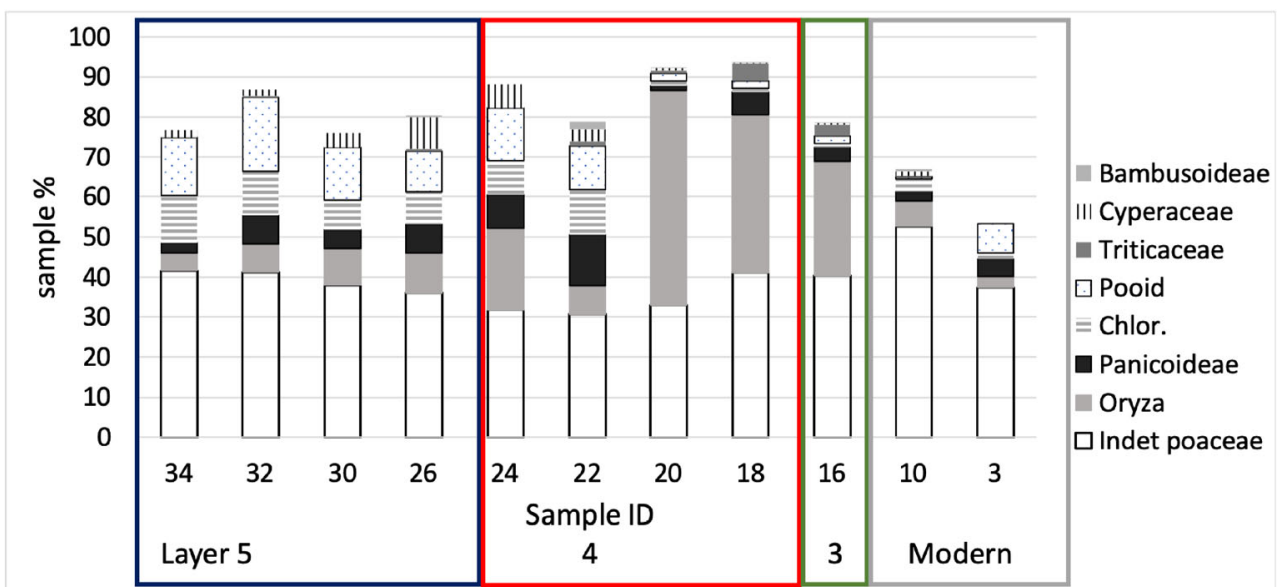


Table 4 Breakdown of Oryza phytoliths percentage in relation to each sample sensitive: fixed ratio per sample from Dayingzhuang. From Dal Martello 2020

\begin{tabular}{llll}
\hline Layer & Sample ID & Oryza morphotypes \% & S:F ratio \\
\hline Modern & 3 & 2.72 & 0.87 \\
& 10 & 6.35 & 2.92 \\
3 & 16 & 28.45 & 3.08 \\
4 & 18 & 39.54 & 0.51 \\
& 20 & 53.71 & 1 \\
& 22 & 7.09 & 0.51 \\
& 24 & 20.19 & 0.74 \\
5 & 26 & 9.96 & 1.02 \\
& 30 & 9.15 & 0.93 \\
& 32 & 7.03 & 0.75 \\
& 34 & 4.51 & 0.98 \\
\hline
\end{tabular}

based mainly on rainfall or rainy season flood recession. In general, $800 \mathrm{~mm}$ of rainfall is regarded as the minimal precipitation to support rainfed rice (Jacquot and Courtois 1987; Fuller et al. 2011). Nevertheless, some caution is warranted as it is possible that the samples come from multiple activities and inputs and do not only reflect plants harvested from agricultural fields; larger scale phytolith analyses across multiple contexts in each period would be needed to clarify this, but the high levels of rice phytoliths suggests that rice crop waste was a major source of phytoliths. We therefore tentatively conclude that drier field conditions closer to traditional rainfed cultivation persisted up until Layer 3, with more intensive, irrigated rice cultivation starting sometime after the fourth century BC. These

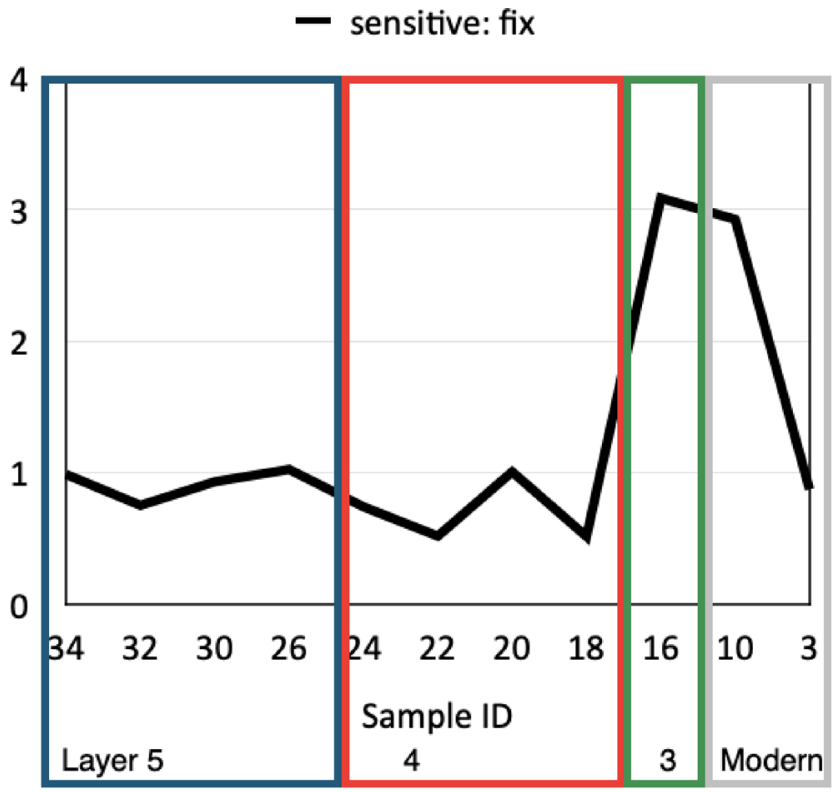

Fig. 20 Sensitive: fixed phytolith ratio per sample at Dayingzhuang phytolith data could support the inference from pollen, that more intensive and irrigated rice cultivation became widespread during the Dian period in the later 1st Millennium BC (Sun et al. 1986; Yao 2016; Xiao et al. 2020).

\section{Discussion: characterizing Dian agriculture}

Current archaeobotanical studies in Yunnan have shown how agricultural practices in the region started from at least the mid-3rd millennium BC (Dal Martello et al. 2018; Dal Martello 2020). At the site of Baiyangcun, remains of morphologically domesticated rice and Chinese millets (Setaria italica, Panicum miliaceum) have been found together dating from about 2650 cal BC. The mixed rice-millet farming at Baiyangcun persisted until ca. $1600 \mathrm{BC}$ and the two crops have also been found together at the slightly later site of Dadunzi, dating to AMS 2140-1630 cal BC, also located in Northwest Yunnan. At present, the archaeobotanical evidence points to a millets-rice mixed crop agriculture that came into the province from the north as the earliest form of agriculture in the region. This type of agriculture is well suited to the vertical zonation of landscape present in Yunnan. The vertical zonation coupled with the rich hydrological network allows for a variety of environmental niches to co-exist within short distances, with well-watered rice in the lower alluvial plains, and rainfed millet further away from water and surrounding slopes.

Remains of wheat and barley in Yunnan have been found at sites dating to at least a millennium later than the first appearance of agricultural crops in the province. Both wheat and barley have been reported from the second period of occupation at Haimenkou, in the Jinsha basin, Northwest Yunnan. Here, the crops have been directly dated through AMS radiocarbon dating to ca. 1400 BC (Xue 2010; Jin 2013; Dal Martello 2020). Wheat has also been reported from the Dian site of Shangxihe, in central Yunnan; this site, although culturally associated with the Dian, has been dated to c. 1200 200 BC (Yao et al. 2020; YPICRA et al. 2019), which predates the traditional beginning of the Dian by several hundred years, and wheat grains have been directly dated to 1095 $933 \mathrm{BC}$ at the earliest occurrence (Yao et al. 2020). Instead, almost all of the sites dating to the 1st millennium BC have reported wheat and barley remains, indicating that the crops had dispersed widely in the province by the 1 st millennium BC. These include the Dian sites of Shangxihe, Shizhaishan, Hebosuo, Anjiang, Xueshan, Guangfentou, and Xiaogucheng, with the exclusion of Shangxihe, all roughly dating from the eighth century BC onward (i.e. Wang 2014; Yang 2016; Li and Liu 2016; Yao et al. 2015).

There are still debates on the route and timing through which wheat and barley reached Yunnan, with earlier evidence in both South Asia and Central Asia (Fig. 11). One 
Fig. 21 Comparison of Sensitive: Fixed values from published sites in China and Southeast Asia, data from Fuller et al. 2016

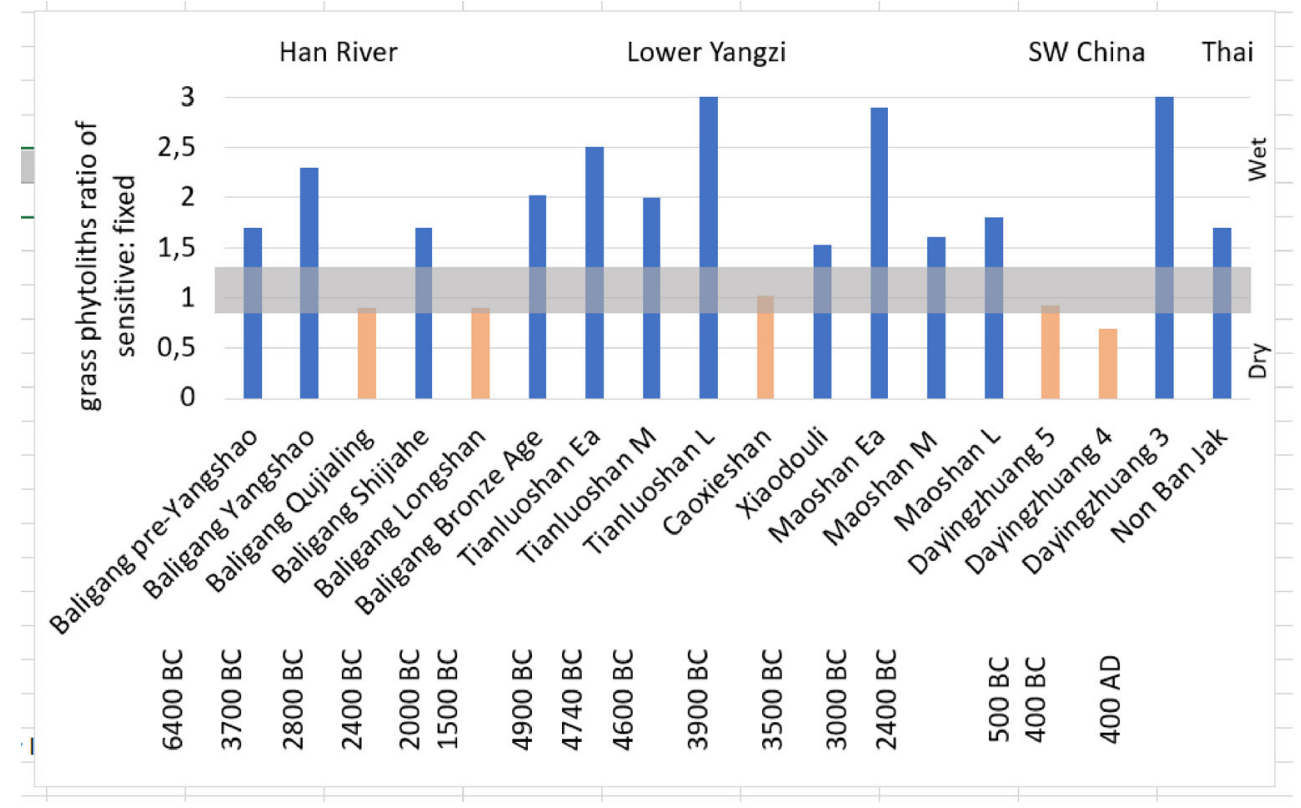

hypothesis is that they spread together through the southward dispersal of populations from Northwest China during the Bronze Age. This is supported by changes in material culture and general subsistence composition, such as at Haimenkou where an increase of sheep/goat remains took place alongside the appearance of wheat and barley, present by ca. $1400 \mathrm{BC}$ (e.g. Xue 2010; Stevens et al. 2016; Dal Martello 2020). This period also indicated increased population at the site, with a rise in houses and tree-cutting tools. However, in much northern and central China early wheat occurred in the absence of evidence for barley so it may not be the case that these crops spread together (e.g. Flad et al. 2010; Boivin et al. 2012; Liu et al. 2017; Deng et al. 2020). Wheat and barley co-occur the site of A'shaonao, on the eastern edge of the Tibetan Plateau

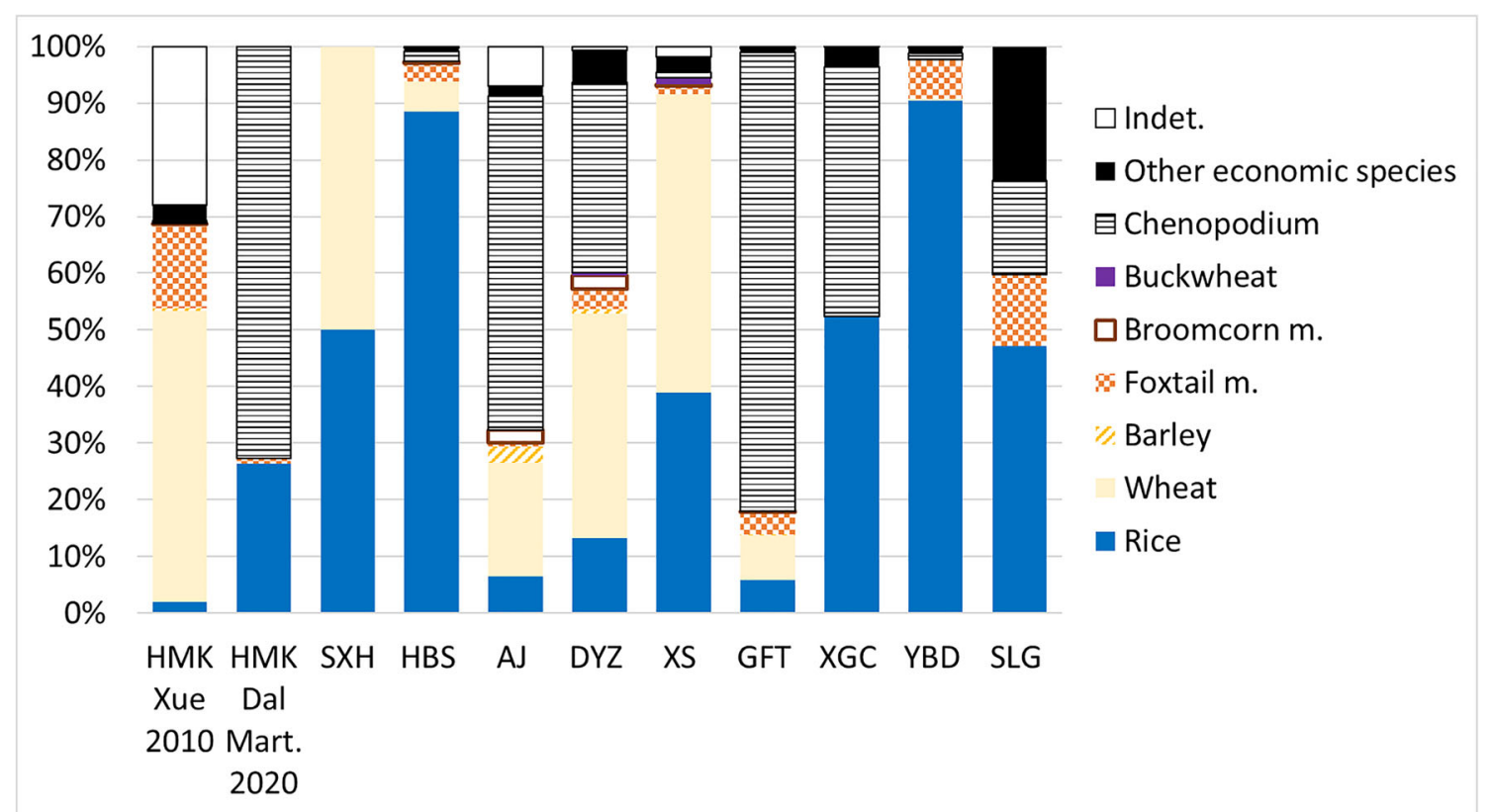

Fig. 22 Comparison of frequency index for sites in Yunnan with flotation, dating between c. 1000-300 BC. The site initials are used to indicate the site $(\mathrm{HMK}=$ Haimenkou; $\mathrm{SLG}=$ Shilingang; $\mathrm{YBD}=\mathrm{Yubeidi}$; HBS= Hebosuo; AJ= Anjiang; DYZ= Dayingzhuang; $\mathrm{XS}=\mathrm{Xueshan}$; $\mathrm{GFT}=$ Guangfentou; $\mathrm{XGC}=$ Xiaogucheng) $. \mathrm{HMK}=$ Haimenkou refers to the 3rd period of occupation of the site dated to between 800-400 BC. Data from: Dal Martello 2020; Xue 2010; Jin 2013; Yao et al. 2015; Li et al. 2016; Wang 2014; Li and Liu 2016). Remade from Dal Martello 2020 
in Sichuan, where the crops have been directly dated to c. 1400 BC (d'Alpoim Guedes et al. 2015), contemporary to the finds of Haimenkou.

An alternative hypothesis posits that the arrival of barley in China came from the southwest (from India) separately from the arrival of wheat from Central Asia to Northwest China at the end of the Neolithic (e.g. Lister et al. 2018). Currently, there is limited evidence of the arrival of barley, and available dating evidence for neither route is conclusive. When present in Yunnan, barley appears as minor and always co-occurs with more substantial quantities of wheat. Recently obtained direct radiocarbon dates on barley grains recovered from interior sites on the northeastern Tibetan Plateau are earlier than those from either Xinjiang (northwest) and southern Tibet (southwest). At the site of Xiasunjiazhai, on the northeastern side of the Tibetan Plateau in Qinghai province, barley grains have been dated to 21361959 cal BC (Liu et al. 2017), whereas at the sites of Sidaogou and Yanghai, in Xinjiang, barley dates to 978-831 cal BC and 750-405 cal BC respectively, and at Khog gzung and Bangtangbu, on the south-western Tibetan Plateau, it dates to 1393-1211 cal BC, and 1263-1056 cal BC respectively (Liu et al. 2017; Lister et al. 2018), which is similary to both dates from Haimenkou and A'shaonao. Outside China, evidence relating a posited northwestern/Central Asia source include barley finds from Ojakly in Turkmenistan 1617-1498 cal BC, Tasbas in Kazakhstan 1437-1233 cal BC; and Aigyrchal-2 in Kyrgyzstan 1630-1497 cal BC (Spengler 2015; Lister et al. 2018); these are not earlier than Xiansunjiazhai and again comparable to dates from Haimenkou and A'shaonao. Barley finds that might relate to precursors on the Southwestern route, include grains from Kanispur in Kashmir directly dated to 24672236 cal BC (Liu et al. 2017), or evidence from the Lower Ganges valley at Chirand in Bihar, where barley and rice are present with associated dates from 1920 to $1660 \mathrm{BC}$ (VishnuMittre 1972; Fuller 2011). In Nepal, the only early archaeobotanical evidence places barley in the eastern Himalayas, at the site of Chokhopani, from ca. 1000 BC (Knörzer 2000). Currently, the route or routes by which barley arrived in Yunnan are unclear, as well as whether this took place with wheat or other cultural elements. Genetic data from goats suggests a dispersal took place from South Asia to Southeast and Southwest China (mt-DNA haplogroup B) separately from a dispersal from Central Asia into China (haplogroup A; see Lin et al. 2013; Waki et al. 2015). In contrast, Chinese sheep, like wheat, appear to have arrived from Central Asia via the Northwest and/or Mongolia (Sun et al. 2010). Further archaeological evidence is needed to resolve when domesticates arrived from the Southwest into China as distinct from those that arrived via the Northwest.

The recent archaeobotanical studies carried out at the sites within the Dian sphere of influence (including sites surrounding Lakes Dian, Fuxian, and Xingyun) illustrate what can be described as the "Dian agricultural system". This is characterised by a high mixture of crops, including seasonally differentiated crops, such as summer rice and millets, both foxtail and broomcorn millet, and winter wheat and barley (Fig. 22). The specific ratio of these species varies among each site; however, rice and wheat seem to be the two most prevalent species found across all sites (Fig. 22). Additionally, Chenopodium remains have also been reported in considerable quantities, especially at the site of Guangfentou ( $\mathrm{Li}$ and Liu 2016). Chenopodium can be exploited as a food resource, and historically it has been a minor crop, and trade item, in parts of the Himalayas and Tibet up to the present day, including being cultivated for both its seeds and leaves among the Formosan tribes in highland Taiwan. Few scholars have proposed that this species might have been exploited as food at other nearby Chinese earlier sites of Haimenkou (Xue 2010; Dal Martello) in northwestern Yunnan and Guiyuanqiao in Sichuan (d'Alpoim et al. 2015); however, there has been no systematic exploration of this issue in the context of Dian Yunnan. The consistent finding of a high quantity of Chenopodium from early sites in Yunnan deserves future scholarly attention and archaeobotanical investigation. Finally, the archaeobotanical record shows only a limited input from wild resources. Nevertheless, some intensive use of wild aquatic animal resources was likely. Sites like Dayingzhuang, which is a shell-midden, included numerous lacustrine remains (fish and shellfish). No in depth zooarchaeological analyses have been published from this period from which to address the role of pigs, which were certainly present in the region since the Neolithic (Wang 2018), or whether any domesticated bovids were yet present.

It is posited that general weather conditions in the Dian Basin during the 1st millennium were largely comparable to those of present day, albeit fluctuating. Today, modern agriculture is characterised by multiple crops per year, with a harvest of summer rice and a harvest of winter wheat (Zhao 1986). The fluctuating climate might have had a role in encouraging the preservation of this highly mixed crop system.

\section{Conclusion}

The variety of crops recovered from all of these sites suggest that already during the Dian, people were taking advantage of the vertical landscape and multiple seasons of agriculture to maximise production. Wet rice fields are likely to have been concentrated at the bottom of the valley, with cultivation of rainfed crops on the off seasons (winter) or in the surrounding hills (summer millet). These two seasons of agriculture represent intensification of land use since the Neolithic when cropping was only focused on the summer. Further intensification of summer rice could have taken place through artificial irrigation to maintain higher water levels and transplanting. At present, it is still difficult to establish when this happened, 
although its presence in the Han period is generally agreed, and the high sensitive: fixed phytolith ratio from Layer 3 would support its presence at Dayingzhuang before the site was abandoned around the fourth century BC.

Supplementary Information The online version contains supplementary material available at https://doi.org/10.1007/s12520-020-01268-y.

Acknowledgements We thank the Yunnan Province Institute of Archaeology and Cultural Relics for permission and support in carrying out these analyses. Peking University (PKU) School of Archaeology and Museology and International Centre for Chinese Heritage and Archaeology of PKU and UCL facilitated the development of research collaboration in archaeobotany between UCL and the Yunnan Institute. We are grateful to Min Rui and Dr. Qin Ling for facilitating and encouraging this collaboration. Travel between the UK and Yunnan and AMS dating were supported for the Comparative Pathways to Agriculture (ComPAg) project of DF supported by a ERC grant (no. 323842). Laboratory analyses were carried out by RDM as part of her $\mathrm{PhD}$, which was funded by an Arts and Humanities Research Council (AHRC) London Arts and Humanities Partnership (LAHP) Doctorate Research Studentship. We also thank Dr. Chris Stevens for his consultations on identifications and for providing comparative measurements on millets from other Chinese sites.

Authors' contributions RDM drafted and DQF revised the manuscript, LXR conducted flotation and directed the excavation of the site. RDM carried out the laboratory; DQF aided with identifications.

Funding RDM's doctorate research was funded by an Arts and Humanities Research Council (AHRC) London Arts and Humanities Partnership (LAHP) Doctorate Research Studentship. Excavation by LXR was funded by the Yunnan Province Institute of Cultural Relics and Archaeology. Travel for fieldwork by RDM, aspects of laboratory analysis and AMS dating of wheat grains were supported by the European Research Council (ERC) advanced grant "Comparative Pathways to Agriculture" (no. 323842). The writing of this manuscript was supported by the ERC starter grant "Fruits of Eurasia: Domestication and Dispersal" (no. 851102).

Data availability Data are included as supplementary files to this publication. Flotation samples are stored with the Yunnan Province Institute of Archaeology and Cultural Relics. Sorted, photographed, and measured seeds as well as phytolith slides are currently in the archaeobotany laboratory at UCL and due to be returned to Yunnan for long-term archiving.

\section{Compliance with ethical standards}

Conflict of interest The authors declare that they have no conflict of interest.

Open Access This article is licensed under a Creative Commons Attribution 4.0 International License, which permits use, sharing, adaptation, distribution and reproduction in any medium or format, as long as you give appropriate credit to the original author(s) and the source, provide a link to the Creative Commons licence, and indicate if changes were made. The images or other third party material in this article are included in the article's Creative Commons licence, unless indicated otherwise in a credit line to the material. If material is not included in the article's Creative Commons licence and your intended use is not permitted by statutory regulation or exceeds the permitted use, you will need to obtain permission directly from the copyright holder. To view a copy of this licence, visit http://creativecommons.org/licenses/by/4.0/.

\section{References}

Allard F (1999) The archaeology of Dian: trend and traditions. Antiquity 73(279):77-85

Asouti E, \& Fuller DQ (2008) Trees and woodlands of South India: archaeological perspectives. Left Coast Press

Barton L, Newsome SD, Chen FH, Wang H, Guilderson TP, Bettinger RL (2009) Agricultural origins and the isotopic identity of domestication in northern China. Proc Natl Acad Sci 106(14):5523-5528

Boivin N, Fuller DQ, Crowther A (2012) Old World globalization and the Columbian exchange: comparison and contrast. World Archaeol 44(3):452-469

Bray F (1984) Science and Civilisation in China vol. 6. Biology and biological technology. Part II Agriculture. Cambridge University Press, Cambridge

Castillo CC, Tanaka K, Sato YI, Ishikawa R, Bellina B, Higham C, Chang N, Mohanty R, Kajale M, Fuller DQ (2016) Archaeogenetic study of prehistoric rice remains from Thailand and India: evidence of early japonica in South and Southeast Asia. Archaeol Anthropol Sci 8(3):523-543

Chanchala S (2002) Botanical remains. Excavations at Charda166-194

Crawford G, Chen X, Wang J (2006) Shandong Jinan Changqingqu Yuezhuang Yizhi Faxian Houli Wenhua Shiqi de Tanhuadao [charred rice discovery from the Houli site of Yuezhuang, Jinan Changqing district, Shandong] (in Chinese). Dongfang Kaogu 3: 247-251

D'Alpoim Guedes JD, Jiang M, He K, Wu X, Jiang Z (2013) Site of Baodun yields earliest evidence for the spread of rice and foxtail millet agriculture to south-West China. Antiquity 87(337):758-771. https://doi.org/10.1017/S0003598X00049449

Dal Martello R (2020) Agricultural trajectories in Yunnan, Southwest China: a comparative analysis of archaeobotanical remains from the Neolithic to the Bronze Age. Dissertation. University College London

Dal Martello R, Min R, Stevens C, Higham C, Higham T, Qin L, Fuller DQ (2018) Early agriculture at the crossroad of China and Southeast Asia: archaeobotanical and radiocarbon dates from Baiyangcun, Yunnan. Journal of Archaeological Science: Reports 20:711-721

D'Alpoim Guedes J (2013) Adaptation and invention during the spread of agriculture in Southwest China. Dissertation, Harvard University

d'Alpoim Guedes J, Wan J (2015) Sichuan Shenfangshi Guiyuanqiao yizhi fuxuan Jieguo yu fenxi [Millets, Rice and Early Agriculture on the Chengdu Plain: Results from the Site of Guiyuanqiao] (in Chinese). Sichuan Wenwu 183(5):81-94

D'Alpoim Guedes J, et al. (2009) Niandu kaogu shijue fuxuan jieguo fenxi jianbao [preliminary flotation results from the 2009 excavation at the site of Baodun in Xinlu] (in Chinese). Chengdu Kaogu Faxian, pp 68-82

d'Alpoim Guedes JA et al (2015) Early evidence for the use of wheat and barley as staple crops on the margins of the Tibetan plateau. Proc Natl Acad Sci 112(18):5625-5630

Dearing JA, Jones RT, Shen J, Yang X, Boyle JF, Foster GC, Crook DS, Elvin MJ (2008) Using multiple archives to understand past and present climate-human-environment interactions: the lake Erhai catchment, Yunnan Province, China. J Paleolimnol 40(1):3-31

Deng Z (2016) Hanshui zhongxiayou shiqian nongye yanjiu [Prehistoric agriculture in the middle and lower Hanshui River] (in Chinese). Dissertation, Peking University

Deng Z, Fuller DQ, Chu X, Cao Y, Jiang Y, Wang L, Lu H (2020) Assessing the occurrence and status of wheat in late Neolithic Central China: the importance of direct AMS radiocarbon dates from Xiazhai. Veg Hist Archaeobotany 29(1):61-73

Dykoski CA, Edwards RL, Cheng H, Yuan D, Cai Y, Zhang M, Lin Y, Qing J, An Z, Revenaugh J (2005) A high-resolution, absolute-dated 
Holocene and deglacial Asian monsoon record from Dongge cave, China. Earth Planet Sci Lett 233(1-2):71-86

Flad R, Shuicheng L, Xiaohong W, Zhijun Z (2010) Early wheat in China: results from new studies at Donghuishan in the Hexi corridor. The Holocene 20(6):955-965

Fuller DQ (2000) The emergence of agricultural societies in South India: botanical and archaeological perspectives. Dissertation, University of Cambridge

Fuller DQ (2011) Finding plant domestication in the Indian subcontinent. Curr Anthropol 52(S4):S347-S362

Fuller DQ, Sato YI, Castillo C, Qin L, Weisskopf AR, Kingwell-Banham EJ, Song J, Ahn SM, Van Etten J (2010) Consilience of genetics and archaeobotany in the entangled history of rice. Archaeol Anthropol Sci 2(2):115-131

Fuller DQ, Van Etten J, Manning K, Castillo C, Kingwell-Banham E, Weisskopf A, Qin L, Sato YI, Hijmans RJ (2011) The contribution of rice agriculture and livestock pastoralism to prehistoric methane levels: an archaeological assessment. Holocene 21(5):743-759

Fuller DQ, Denham T, Arroyo-Kalin M, Lucas L, Stevens CJ, Qin L, Allaby RG, Purugganan MD (2014) Convergent evolution and parallelism in plant domestication revealed by an expanding archaeological record. Proc Natl Acad Sci 111(17):6147-6152

Fuller DQ, Weisskopf AR, Castillo C (2016) Pathways of rice diversification across Asia. Archaeol Int 19:84-96

Harvey E, Fuller DQ (2005) Investigating crop processing using phytolith analysis: the example of rice and millets. J Archaeol Sci 32:739-752

Hillman AL, Yu J, Abbott MB, Cooke CA, Bain DJ, Steinman BA (2014) Rapid environmental change during dynastic transitions in Yunnan Province, China. Quat Sci Rev 98:24-32

Hillman AL, Abbott MB, Finkenbinder MS, Yu J (2017) An 8,600 year lacustrine record of summer monsoon variability from Yunnan, China. Quaternary Sci Rev 174:120-132

Huang F, Zhuang M (2000) Pollen and phytolith evidence for rice cultivation during the Neolithic at Longquizhuang, eastern Jainghuai, China. Veg Hist Archaeobotany 9:161-168

Jacquot M, Courtois B (1987) Upland Rice. The Tropical Agriculturalist series. CTA, Paris

Jenkins E, Jamjoum K, Nuimat S (2011) Irrigation and phytolith formation: an experimental study. In: Mithen S, Black E (eds) Water, life, and civilisation: climate, environment and Society in the Jordan Valley. Cambridge University Press, Cambridge, pp 347-372

Jin H (2013) Haimenkou yizhi zhiwu yicun zonghe yanjiu [study on the archaeobotanical remains from Haimenkou] (in Chinese). Dissertation, Peking University

Kingwell-Banham E (2019a) Dry, rainfed or irrigated? Reevaluating the role and development of rice agriculture in Iron Age-Early Historic South India using archaeobotanical approaches. Archaeol Anthropol Sci 11(12):6485-6500

Kingwell-Banham E (2019b) The spread of rice across peninsula India (and Sri Lanka). Presentation given at the Rice Workshop, Vadodara

Knörzer KH (2000) 3000 years of agriculture in a valley of the high Himalayas. Veg Hist Archaeobotany 9(4):219-222

Lee G-A, Bestel S (2007) Contextual analysis of plant remains at the Erlitou-period Huizui site, Henan, China. Bull Indo-Pacific Prehistory Assoc 27:49-60

Li F (1994) Ruzhou Lilou yizhi chutu tanhua liangwei de jianding [identification of carbonized grains unearthed from the Lilou site in Ruzhou] (in Chinese). Kaogu Xuebao 1:96-97

Li X, Liu L (2016) Yunnan Jiangchaun Guangfentou yizhi zhiwu yicun fuxuan jieguo ji fenxi [flotation report on the analysis on the archaeobotanical remains from the site of Guangfentou, Jiangchuan, Yunnan] (in Chinese). Kaogu Xuebao 3:20-27

Li H, Zuo X, Kang L, Ren L, Liu F, Liu H, Zhang N, Min R, Liu X, Dong $G$ (2016) Prehistoric agriculture development in the YunnanGuizhou plateau, Southwest China: archaeobotanical evidence. Science China Earth Sciences 59(8):1562-1573
Lin BZ, Odahara S, Ishida M, Kato T, Sasazaki S, Nozawa K, Mannen H (2013) Molecular phylogeography and genetic diversity of East Asian goats. Anim Genet 44(1):79-85

Lister DL, Jones H, Oliveira HR, Petrie CA, Liu X, Cockram J, Kneale CJ, Kovaleva O, Jones MK (2018) Barley heads east: genetic analyses reveal routes of spread through diverse Eurasian landscapes. PloS one 13(7): 0196652

Liu L, Lee G-A, Jiang L, Zhang J (2007) Evidence for the early beginning (c. 9000 cal BP) of rice domestication in China: a response. The Holocene 17(8):1059-1068

Liu X, Lister D, Zhao Z, Petrie CA et al (2017) Journey to the east: diverse routes and variable flowering times for wheat and barley en route to prehistoric China. PLoS One 12(11):e0209518

Madella M, Alexandré A, Ball T (2005) International code for phytolith nomenclature 1.0. Ann Bot 96(2):253-260

Madella M, Jones MK, Echlin P, Powers-Jones A, Moore M (2009) Plant water availability and analytical microscopy of phytoliths: implications for ancient irrigation in arid zones. Quaternary International 193(1-2):32-40

National Bureau of Statistics of China (NBS) (2019) National Data. http:// data.stats.gov.cn/english/easyquery.htm?cn=E0103. Accessed 18 January 2019

Pei A (1998) Notes on new advancements and revelations in the agricultural archaeology of early rice domestication in the Dongting Lake region. Antiquity 72:878-885

Piperno DR (2006) Phytoliths: a comprehensive guide for archaeologists and paleoecologists. Altamira Press, Oxford

Pokharia A, Kharakwal J, Rawat R, Osada T, Nautiyal C, Srivastava A (2011) Archaeobotany and archaeology at Kanmer, a Harappan site in Kachchh, Gujarat: evidence for adaptation in response to climatic variability. Curr Sci 100(12):1833-1846

Qian S (1993) Records of the Grand Historian of China. Translated by Burton Watson. Columbia University Press, New York

Rosen AM (1999) Phytoliths protocol. University College London, Institute of Archaeology, London

Saraswat KS (2004) Early farming communities of the Kaimur (excavations at Senuwar)

Shanghai Museum (2014) Guangfulin- Kaogu Fajue yu Xueshu Yanjiu lunji [proceedings on the excavation at Guangfulin] (in Chinese). Shanghai Guji press

Shen J, Yang L, Yang X, Matsumoto R, Tong G, Zhu Y, Zhang Z, Wang S (2005) Lake sediment records on climate change and human activities since the Holocene in Erhai catchment, Yunnan Province, China. Sci China Series D: Earth Sci 48(3):353-363

Sheng P, Zhou H, Liu J, Jiang H (2020) Some like it hot: Sichuan pepper (Zanthoxylum bungeanum) and other spices from a late Bronze Age kingdom (Chu State) in Hubei, China. Archaeol Anthropol Sci 12: 249. https://doi.org/10.1007/s12520-020-01201-3

Spengler RN (2015) Agriculture in the central Asian bronze age. J World Prehist 28(3):215-253

Spengler RN, Willcox G (2013) Archaeobotanical results from Sarazm, Tajikistan, an Early Bronze Age settlement on the edge: agriculture and exchange. Environ Archaeol 18(3):211-221

Spengler RN, Frachetti M, Doumani P, Rouse L, Cerasetti B, Bullion E, Mar'yashev A (2014) Early agriculture and crop transmission among bronze age mobile pastoralists of Central Eurasia. Proc R Soc B Biol Sci 281(1783):20133382

Stevens CJ, Murphy C, Roberts R, Lucas L, Silva F, Fuller DQ (2016) Between China and South Asia: a Middle Asian corridor of crop dispersal and agricultural innovation in the Bronze Age. Holocene 26(10):1541-1555

Stevens CJ, Lavi-Shelach G, Zhang H, Teng M, Fuller DQ (2020) A model for the domestication of common, proso or broomcorn millet (Panicum miliaceum) in China. Vegetation History and Archaeobotany. https://doi.org/10.1007/s00334-020-00804-z 
Sun X, Wu Y, Qiao Y, Walker D (1986) Late Pleistocene and Holocene vegetation history at Kunming, Yunnan Province, Southwest China. J Biogeogr 13(5):441-476

Sun W, Chang H, Tsunoda K, Musa HH, Yang ZP, Ma YH, Guan WJ (2010) The phylogeographic system survey of native sheep breeds in the eastern and southern Central Asia. J Anim Breed Genet 127(4):308-317

Tang L (1999) [identification and analyses of rice remains from the Longqiuzhuang site] (in Chinese). In: Longqiuzhuang archaeology Team, ed. Wenwu Press, Longqiuzhuang, pp 441-448

Tang S, Sato Y, Yu W (2003) Hemudu tanhuadao zhongpu yesheng daoguli de faxian [Discovery of normal wild rice grains from charbonized rice at Hemudu] (in Chinese). In Zhejiang Institute of Archaeology, ed., Hemudu. Wenwu Press, pp. 440-44

Vishnu-Mittre SR (1972) The Neolithic plant economy of Chirand, Bihar. The Palaeobotanist 21:18-22

Vishnu-Mittre SR (1982) Food economy of the Harappans. Harrapan Civilization. Oxford and IBH, New Delhi, pp 205-221

Waki A, Sasazaki S, Kobayashi E, Mannen H (2015) Paternal phylogeography and genetic diversity of East Asian goats. Anim Genet 46(3):337-339

Wang Q (2014) Yunnan Hebosuo yu Yubeidi yizhi Zhiwu yicun Fenxi [analysis of the archaeobotanical remains found at Xueshan site, in Dengjiang county, Yunnan] (in Chinese). Dissertation. Shandong University

Wang J (2018) A Zooarchaeological Study of the Haimenkou Site, Yunnan Province, China. Archaeology of East Asia vol. 1 ed. BAR international series, 2902

Weisskopf AR, Qin L, Ding J, Ding P, Sun G, Fuller DQ (2015) Phytoliths and rice: from wet to dry and back again in the Neolithic lower Yangtze. Antiquity 89(347):1051-1063

Wu X, Hein A, Zhang X, Jin Z, Wei D, Huang F, Yin X (2019) Resettlement strategies and Han imperial expansion into southwest China: a multimethod approach to colonialism and migration. Archaeol Anthropol Sci 11:6751-6781

Xiao X, Yao A, Hillman A, Ji S, Haberle SG (2020) Vegetation, climate and human impact since $20 \mathrm{ka}$ in Central Yunnan Province based on high-resolution pollen and charcoal records from Dianchi, southwestern China. Quaternary Science Reviews 236:106297

Xue Y (2010) Yunnan Haimenkou yizhi zhiwu yicun chubu yanjiu [preliminary study on the archaeobotanical remains from Haimenkou] (in Chinese). Dissertation, Peking Univerisity

Yang W (2016) Yunnan Hebosuo he Yubeidi yizhi zhiwu yicun fenxi [analysis on the archaeobotanical remains from the sites of Hebosuo and Yubeidi, Yunnan] (in Chinese). Dissertation, Shandong University

Yang X, Liu C (2009) 汉阳陵外藏坑农作物遗存分析及西汉早期农业 Han Yangling Waizengkeng Nongzuowu Yicun Fenxi Ji Xihan Zaoqi Nongye [Early Agriculture in the Western Han: Analysis of the Agricultural Products of from the Han Yanling Tomb]. (in Chinese). Kexue Tongbao 2009(54):1917-1921

Yao A (2016) The ancient highlands of Southwest China: from bronze Age to the Han Empire. Oxford University Press, New York

Yao A (2017) Politics of time on the southwest frontier of China's Han empire. Am Anthropol 119(1):86-103
Yao A, Jiang Z (2012) Rediscovering the settlement system of the "Dian" kingdom, in Bronze Age southern China. Antiquity 86:353-367

Yao A, Jiang Z, Chen X, Liang Y (2015) Bronze Age weland/scapes: complex political formations in the humid subtropics of southwest China, 900-100 BC. J Anthropol Archaeol 40:213-229

Yao A, Darré V, Zhilong J, Lam W, Wei Y (2020) Bridging the time gap in the Bronze Age of Southeast Asia and Southwest China (long title). Archaeological Research in Asia 22:100189

Yunnan Province Archaeological Team (YPAT) (1965) Yunnan Anning Taijishan Gumuzang qingli Jianbao [excavation of ancient tombs at T'ai Chi Shan in Anning County, Yunnan Province] (in Chinese). Kaogu 9:451-458

Yunnan Province Institute for Cultural Relics and Archaeology (YPICRA), University of Chicago (2019) Yunnan Jinning Hebosuo he Shangsihe yizhi qingtong shidai beiqiu yizhi shijue jianbao [preliminary report on the excavation of the sites of Shangxihe and Hebosuo in Jinning, Yunnan] (in Chinese). Jianghan kaogu 2:17-29

Yunnan Province Institute of Cultural Relics and Archaeology (YPICRA), University of Michigan, Michigan Museum of Anthropology (2015) Yunnan Dianchi Pendi 2010 Juluo Kaogu Diaocha Jianbao [preliminary findings from the 2010 archaeological survey in Lake Dian Basin, Yunnan] (in Chinese). Kaogu 5:29-36

Yunnan Provincial Museum (1963) Yunnan Jijing Shizhaishan Gumu disi fajue jianbao [Preliminary report on the fourth season of excavation at the cemetery of Shizhaishan, Jijing, Yunnan] (in Chinese). Kaogu 1:480-485 +6-8

Zhang Z (1997) Dianguo yu Dianwenhua [Dian kingdom and Dian culture] (in Chinese). Yunnan Arts Press, Kunming

Zhang J, Wang X (1999) Notes on the recent discovery of ancient cultivated rice at Jiahu, Henan Province: a new theory concerning the origin of Oryza japonica in China. Antiquity 72(278):897-901

Zhao S (1986) Physical geography of China. Wiley, New York

Zhao S (1994) Geography of China: environment, resources, population, and development. John Wiley \& Sons, New York

Zhao Z (2003) Yunnan Yongren Mopandi Xinshiqi Shidai yizhi chutu daobu yicun fenxi [analysis on the rice remains from the Neolithic site of Mopandi, Yongren, Yunnan] (in Chinese). Kaogu Xuebao 4: 294-296

Zhao Z (2011) New archaeobotanical data for the study of the origins of agriculture in China. Curr Anthropol 52(S4):S295-S306

Zheng Y, Jiang L, Zheng J (2004) Zhejiang Kuahuqiao yizhi de gudao yicun yanjiu [study on the remains of ancient rice from Kuahuqiao site in Zhejiang Province] (in Chinese). Zhongguo Shuidao Kexue 2:33-38

Zhou X, Yu J, Spengler RN, Shen H, Zhao K, Ge J, Bao Y, Liu J, Yang Q, Chen G, Jia PW (2020) 5,200-year-old cereal grains from the eastern Altai Mountains redate the trans-Eurasian crop exchange. Nature Plants 6(2):78-87

Publisher's note Springer Nature remains neutral with regard to jurisdictional claims in published maps and institutional affiliations. 